\title{
SPIDER WEB ATAU SHAJARAH AL-'ILM?: Mencari Format Ideal Kajian Hadis Integratif di Indonesia
}

\author{
Nothen \\ Benny Afwadzi \\ Universitas Islam Negeri Maulana Malik Ibrahim Malang \\ e-mail: afwadzi@pai.uin-malang.ac.id
}

\begin{abstract}
Abstrak
Spider Web dan Shajarah al-'Ilm merupakan dua konsep integrasi agama dan ilmu yang populer di Perguruan Tinggi Keagamaan Islam (PTKIN). Konsep pertama dimiliki UIN Sunan Kalijaga Yogyakarta, sedangkan konsep yang kedua dipunyai oleh UIN Maulana Malik Ibrahim Malang. Oleh sebab itu, artikel ini fokus untuk mengulas hadis integratif dalam kedua konsep integrasi agama dan ilmu tersebut. Artikel ini menyimpukan bahwa dalam Spider Web, hadis berada dalam hadhārah al-nashsh yang berdialog dengan hadhārah al"ilm dan dijembatani oleh hadhārah falsafah. Di dalam konsep tersebut juga terdapat kata "sunnah" dalam arti normatifnya dan hadith dalam makna historisnya ('Ulūm al-Dìn), yang kemudian berinteraksi dalam al-Fikr al-Islāmì dan Dirāsat Islāmiyah di kluster selanjutnya. Sementara dalam Shajarah al-'Ilm, hadis Nabi menjadi sumber pengetahuan bersama ilmu-ilmu hasil observasi, eksperimentasi, dan penalaran logis. Dalam metafora konsep tersebut, posisi hadis berada di batang dan dilakukan pembelajaran secara bertahap dan tertata rapi. Kajian dilakukan mulai akar dahulu, kemudian batang, lalu dahan dan ranting, dan diakhiri oleh buah ilmu, iman, amal saleh, dan akhlak yang mulia. Lebih lanjut, artikel ini menemukan beberapa perbedaan antara kajian hadis integratif dalam kedua konsep tersebut, yakni pertama, interaksi keilmuan hadis yang lebih bebas dalam Spider Web, dan munculnya hadis sebagai inspirasi yang tentunya memberi warna baru bagi ilmu pengetahuan dalam Shajarah al-'Ilm; kedua, integrasi hadis yang filosofis dan disukai pegiat studi Islam dalam Spider Web, dan integrasi hadis yang aplikatif dan lebih disukai oleh saintis dalam Shajarah al-'Ilm; dan ketiga, hadis dalam Islamic Studies lebih berkembang dalam Spider Web, dan hadis dalam ilmu umum lebih bisa berkembang dalam Shajarah al-'Ilm.
\end{abstract}

Keywords: Spider Web, Shajarah al-'Ilm, integrasi, interkoneksi

\section{Abstract}

Spider Web and Shajarah al-ImIlm are two concepth of religious and scientific integration that are popular in the Islamic Religious College (PTKIN). The first concept is owned by UIN Sunan Kalijaga 
Yogyakarta, while the second concept is owned by UIN Maulana Malik Ibrahim Malang. Therefore, this article focuses on reviewing integrative traditions in both concepth of integration of religion and science. This article concludes that in Spider Web, hadith are in hadhärah al-Nashsh which dialogue with hadhārah al-'ilm and are bridged by hadharah falsafah. In the concept there is also the word "sunnah" in ith normative meaning and hadith in ith historical meaning ('Ulüm al-Dīn), which then interacth in al-Fikr al-Islämì and Dirāsat Islämiyah in the next cluster. While in Shajarah al-ImIIm, the Prophet's hadith became a source of knowledge along with the science of observation, experimentation, and logical reasoning. In the concept metaphor, the position of the hadith is in the trunk and learning is carried out gradually and neatly arranged. The study is carried out starting at the root first, then the stem, then branches and twigs, and ends with the fruit of knowledge, faith, good deeds, and noble character. Furthermore, this article finds some differences between integrative hadith studies in both concepth, namely first, the freer interaction of hadith scholarship in Spider Web, and the emergence of hadith as inspiration which certainly gives a new color to science in Shajarah al- IIm; second, the integration of hadith which is philosophical and favored by activisth of Islamic studies in Spider $W e b$, and the integration of hadith that is applicable and preferred by scientisth in Shajarah al-ImIIm; and third, hadith in Islamic Studies is more developed in Spider Web, and hadith in general science is more able to develop in Shajarah al-'Ilm.

Keywords: Spider Web, Shajarah al-'llm, integration, interconnection

\section{PENDAHULUAN}

Dewasa ini banyak Perguruan Tinggi Keagamaan Islam Negeri (PTKIN) berlomba-lomba untuk mengimplementasikan pola integrasi keilmuan antara agama dan ilmu, atau dalam istilah lain antara ilmu agama dan ilmu umum dalam kajiankajian yang dilakukannya. ${ }^{1}$ Tidak ditemukan lagi polarisasi istilah ilmu agama dan ilmu sekuler, atau istilah ilmu "Islam" dan ilmu "kafir." Pola kajian integrasi keilmuan ini berpijak pada "penghancuran" dinding-dinding pemisah antara keilmuan agama dan keilmuan umum yang sempat menghegemoni dinamika pemikiran Islam di masa lalu. Baik ilmu agama ataupun ilmu umum secara bersama-sama dikembangkan dan saling berinteraksi satu dengan yang lain. Kenyataan ini jugalah yang mendorong PTKIN mendirikan fakultas-fakultas ilmu

${ }^{1}$ Keinginan adanya integrasi keilmuan ini sebagai sarana memperkuat mutu menjadi sebab beberapa kebijakan yang diambil oleh seperti Kementrian Agama pada saat sekarang ini seperti mendatangkan banyak guru besar dari luar negeri. Dalam waktu sembilan bulan di tahun 2017, Direktorat Jenderal Pendidikan Islam (Ditjen Pendis) telah mendatangkan 22 profesor di bidang nonagama dari Jerman ke berbagai Universitas Islam Negeri untuk menjadi visiting profesor. Lihat, Subdit Penelitian, "Perkuat Mutu dan Kualitas PTKI, Kemenag Datangkan Guru Besar dari Jerman" (11 September 2017), https://kemenag.go.id, diakses 30 September 2017. 
umum, misalnya Fakultas Ilmu Sosial dan Humaniora, Fakultas Sains dan Teknologi, dan Fakultas Kedokteran, serta berkonversi dari sekedar Institut atau Sekolah Tinggi (STAIN dan IAIN) menjadi Universitas (UIN). ${ }^{2}$

Di lingkungan PTKIN sendiri mencuat dua konsep integrasi yang cukup terkenal di kalangan akademisi. Dua konsep tersebut adalah Spider Web (Jaring Laba-Laba) yang ada di UIN Sunan Kalijaga Yogyakarta dan Shajarah al-'Ilm (Pohon Ilmu) di UIN Maulana Malik Ibrahim Malang (selanjutnya disebut Maliki). Meskipun tidak dapat dipungkiri bahwa terdapat konsep-konsep integrasi lain yang dibangun di perguruan tinggi selain dua institusi tersebut, misalnya Wahyu memandu Ilmu (WMI) UIN Sunan Gunung Djati Bandung dan Twin Towers UIN Sunan Ampel Surabaya, akan tetapi paling tidak apabila seseorang hendak menyebut sebuah konsep khusus mengenai integrasi agama dan ilmu, maka agaknya yang mencuat adalah Spider Web dan Shajarah al-'Ilm. Popularitasnya keduanya cukup tinggi di kalangan akademisi Indonesia dan menjadi ciri khas masing-masing institusi tersebut. UIN Sunan Kalijaga terkenal dengan Jaring LabaLabanya dan UIN Maliki populer dengan Pohon Ilmunya.

Menariknya kajian integrasi hadis dan ilmu pengetahuan dalam konsep Jaring Laba-Laba di UIN Sunan Kalijaga dan Pohon Ilmu di UIN Maliki dapat dipahami dari perbedaan latar belakang pembuat kedua konsep dan kondisi akademik di institusinya masing-masing. Perbedaan ini yang nantinya berpotensi untuk mengantarkan pada bentuk integrasi yang cenderung berlainan antara UIN Sunan Kalijaga dan UIN Maliki, meskipun keduanya sama-sama menggenjot pola integrasi agama dan ilmu (atau sains) di kampus masing-masing. Secara lebih jelasnya, perbedaan-perbedaan yang dapat dipaparkan adalah sebagai berikut:

Pertama, Spider Web (Jaring Laba-Laba) UIN Sunan Kalijaga digagas oleh Amin Abdullah yang merupakan seorang ahli filsafat. Ia merupakan tenaga pengajar di Fakultas Ushuluddin dan Pemikiran Islam. Latar belakang sebagai seorang yang bergelut dalam dunia filsafat dan pemikiran Islam ini menjadikan konsep Jaring Laba-Laba penuh dengan ide-ide teoritis dan bernuansa filosofis. Bila dipahami dengan seksama, nilai-nilai filosofis begitu terakar kuat di dalamnya. Sementara itu, Shajarah al- 'Ilm (Pohon Ilmu) UIN Maliki diprakarsai oleh Imam Suprayogo yang bisa disebut sebagai ahli pendidikan Islam. Ia adalah dosen di Fakultas Ilmu Tarbiyah dan Keguruan. Dari latar belakangnya seperti itu menjadikan konsep Shajarah al-'Ilm terasa lebih aplikatif dan bernuansa pendidikan. Ilmu-ilmu ushuluddin memang banyak berkutat pada unsur-unsur teoritis keilmuan, sedangkan ilmu-ilmu tarbiyah atau pendidikan Islam lebih berbicara pada tataran aplikatif di lapangan.

Kedua, kondisi akademik keilmuan agama dan umum antara UIN Sunan Kalijaga dan UIN Maliki cenderung berbeda. Hal ini dapat dilihat, salah satunya

${ }^{2}$ Sampai saat ini tercatat ada tujuh belas Universitas Islam Negeri (UIN) di Indonesia. Ketujuh belas UIN tersebut adalah UIN Sunan Kalijaga Yogyakarta, UIN Syarif Hidayatullah Jakarta, UIN ar-Raniry Banda Aceh, UIN Raden Fatah Palembang, UIN Sunan Ampel Surabaya, UIN Alauddin Makassar, UIN Sunan Gunung Djati Bandung, UIN Walisongo Semarang, UIN Sultan Syarif Kasim Riau, UIN Sumatera Utara, UIN Maulana Malik Ibrahim Malang, UIN Mataram, UIN Imam Bonjol, UIN Antasari Banjarmasin, UIN Sultan Thaha Saifuddin Jambi, UIN Raden Intan Lampung, dan UIN Sultan Maulana Hasanuddin Banten. 
dari distingsi antara kuantitas jurusan agama dan jurusan umum di program strata satu (undergraduate). UIN Sunan Kalijaga mempunyai banyak jurusan keagamaan dibanding jurusan ilmu umumnya, ${ }^{3}$ sedangkan UIN Maliki memiliki lebih banyak jurusan umum daripada jurusan keagamaannya. Pengembangan kampusnya pun boleh dikatakan lebih diarahkan pada jurusan yang mengkaji keilmuan umum dibandingkan keilmuan agama. ${ }^{4}$

Ketiga, UIN Sunan Kalijaga telah mendirikan jurusan Tafsir Hadis, sebagai jurusan yang mengkaji hadis secara intens, sejak tahun 1988 di Fakultas Syariah, akan tetapi pada tahun 1990 jurusan ini pindah ke Fakultas Ushuluddin. Sejak tahun 2013, setelah melalui perdebatan yang cukup alot, jurusan Tafsir Hadis dirubah menjadi jurusan Ilmu al-Qur'an dan Tafsir (IAT) dan pada baru tahun 2015 dibentuk jurusan Ilmu Hadis (ILHA). ${ }^{5}$ Pemisahan bidang ilmu ini sesuai Perat uran Menteri Agama (PMA) yang diedarkan oleh Direktur Jenderal Pendidikan Islam dengan nomor 1429 tahun 2012 tentang Penataan Program Studi di Perguruan Tinggi Agama Islam. ${ }^{6}$ Sejarah panjang jurusan Tafsir Hadis di UIN Sunan Kalijaga tersebut berlainan dengan UIN Maliki yang baru mendirikan jurusan IAT pada tahun 2017 ini dan itu pun berada di Fakultas Syariah yang notebenya bukan merupakan "rumah" dari jurusan tersebut.

Dengan pemaparan di atas, kajian mengenai integrasi hadis dan ilmu pengetahuan di UIN Sunan Kalijaga dan UIN Maliki terasa menarik untuk

${ }^{3}$ Dari data penerimaan mahasiswa baru 2017, jurusan strata satu ilmu keagamaan yang ada di UIN Sunan Kalijaga Yogyakarta berjumlah 24 jurusan, yakni Bahasa dan Sastra Arab, Sejarah dan Kebudayaan Islam, Komunikasi dan Penyiaran Islam, Bimbingan dan Konseling Islam, Pengembangan Masyarakat Islam, Manajemen Dakwah, Ahwâl Syakhsiyah, Perbandingan Madzhab, Hukum Tata Negara (Siyasah), Hukum Ekonomi Syariah (Muamalah), Pendidikan Agama Islam, Pendidikan Bahasa Arab, Manajemen Pendidikan Islam, Pendidikan Guru Madarasah Ibtidaiyah, Pendidikan Islam Anak Usia Dini, Aqidah dan Filsafat Islam, Studi Agama-Agama, Ilmu al-Qur'an dan Tafsir, Ilmu Hadis, Sosiologi Agama, Ekonomi Syariah, Perbankan Syariah, Manajemen Keuangan Syariah, dan Akutansi Syariah. Sementara itu, jurusan ilmu umum hanya berjumlah tujuh belas saja, yaitu Ilmu Perpustakaan, Sastra Inggris, Ilmu Kesejahteraan Sosial, Ilmu Hukum, Matematika, Pendidikan Matematika, Fisika, Pendidikan Fisika, Kimia, Pendidikan Kimia, Biologi, Pendidikan Biologi, Teknik Informatika, Teknik Industri, Psikologi, Sosiologi, dan Ilmu Komunikasi. Lihat http://uin-suka.ac.id/ diakses tanggal 3 Oktober 2017.

${ }^{4}$ Berdasarkan penerimaan mahasiswa baru tahun 2017 UIN Maulana Malik Ibrahim Malang, diperoleh data bahwa jurusan kegamaan di kampus ini berjumlah dua belas jurusan. Dua belas jurusan tersebut adalah Pendidikan Agama Islam, Pendidikan Guru Madrasah Ibtidaiyah, Pendidikan Bahasa Arab, Pendidikan Islam Anak Usia Dini, Manajemen Pendidikan Islam, al-Aḥwâl al-Syakhsiyah, Hukum Bisnis Syariah, Hukum Tata Negara (siyasah), Ilmu al-Qur'an dan Tafsir, Bahasa dan Sastra Arab, Perbankan Syariah (D-3), dan Perbankan Syariah (S-1). Sementara itu, jurusan ilmu umum berjumlah lima belas jurusan, yang terdiri atas Pendidikan IPS, Tadris (Pendidikan) Matematika, Tadris (Pendidikan) Bahasa Inggris, Bahasa dan Sastra Inggris, Psikologi, Manajemen, Akutansi, Matematika, Biologi, Kimia, Fisika, Teknik Informatika, Teknik Arsitektur, Pendidikan Dokter, dan Farmasi. Lihat http://pmb.uin-malang.ac.id// diakses tanggal 3 Oktober 2017. Oktober 2017

5 Lihat, http://iat.uin-suka.ac.id/ dan http://ilmuhadis.uin-suka.ac.id// diakses tanggal 3

${ }^{6}$ Kajian mengenai kebijakan dan dampak peraturan Menteri Agama mengenai pemisahan bidang tafsir dan hadis ini bisa dilihat dalam, Suryadi, "Prospek Studi Hadis di Indonesia: Telaah atas Kajian di UIN, IAIN, dan STAIN," Jurnal Studi Ilmu-Ilmu al-Qur'an dan Hadis, Vol. 16, No. 1 (Juni 2014): 1-16. 
dijabarkan lebih jauh. Kedua institusi ini termasuk yang gencar menyuarakan integrasi agama dan sains. Kajian ini akan menguraikan hakikat konsep masingmasing mengenai integrasi hadis dan ilmu pengetahuan dan juga realisasi konsep yang diusung oleh kedua institusi tersebut dalam kajian-kajian yang dilakukan oleh tenaga pengajarnya. Di samping itu, perbedaan antara konsepsi keduanya juga akan diungkap dalam penelitian ini supaya tergambar jelas bagaimana hakikat integrasi hadis dan ilmu dalam kedua konsep tersebut.

Kajian mengenai integrasi di UIN Sunan Kalijaga dan UIN Maliki serta konsep integrasi di perguruan tinggi lainnya sebenarnya telah banyak dilakukan oleh akademisi dari berbagai perguruan tinggi. Realitas ini disebabkan karena integrasi keilmuan di era kontemporer dianggap sebagai terobosan dalam "kebuntuan" studi ilmiah di Perguruan Tinggi Agama Islam. Kajian ilmu keagamaan dalam pendidikan tinggi Islam tidak dapat berdiri sendiri (isolated entities) dan terpisah dari keilmuan umum. Oleh sebab itu, setiap Perguruan Tinggi Agama Islam berlomba-lomba membangun pola integrasi di kampus masingmasing.

Dari telaah pustaka yang dilakukan, belum ditemukan kajian yang fokus pada integrasi hadis dan ilmu dalam konsep Spider Web dan Shajarah al-'Ilm. Dalam konteks ini, terdapat kajian yang mengulas konsep integrasi antara Islam dan ilmu dalam konteks Perguruan Tinggi Islam secara umum seperti yang dilakukan Andi Rosadisastra, ${ }^{7}$ Lukman Hakim, ${ }^{8}$ Mohammad Muslih, ${ }^{9}$ Nurlena Rifa'i dkk., ${ }^{10}$ dan Abu Darda. ${ }^{11}$ Adapula karya yang mengkaji konsep integrasi di UIN Sunan Kalijaga menjadi bahasan khusus dalam tulisannya seperti karya Mohammad Muslih, ${ }^{12}$ Anshori dan Zainal Abidin, ${ }^{13}$ Waryani Fajar Riyanto, ${ }^{14}$ Afiful Ikhwan,,${ }^{15}$ dan Luthfi Hadi Aminuddin. ${ }^{16}$ Di sisi lainnya, ada karya yang mengulas konsep integrasi di

${ }^{7}$ Andi Rosadisastra, "Integrasi Ilmu Sosial dan Teks Agama dalam Perspektif Tafsir alQur'an,” Mutawatir: Jurnal Keilmuan Tafsir Hadis, Vol. 4, No. 1 (Juni 2014): 87-116.

${ }^{8}$ Lukman Hakim, "Quo Vadis Pengembangan Keilmuan UIN: Sekularisasi atau Qur'anisasi Ilmu Pengetahuan," Substantia: Jurnal Ilmu-Ilmu Ushuluddin, Vol. 16, No. 1 (Juni 2014): 35-48.

9 Mohammad Muslih, "Integrasi Keilmuan: Ide Mutakhir Filsafat Ilmu," Kalimah: Jurnal Studi Agama dan Pemikiran Islam, Vol. 14, No. 2 (Desember 2016): 245-272.

${ }^{10}$ Nurlena Rifa'i dkk,. "Integrasi Keilmuan dalam Pengembangan Kurikulum di UIN seIndonesia: Evaluasi Penerapan Integrasi Keilmuan UIN dan Kurikulum dan Proses Pembelajaran," Tarbiya: Journal of Education in Muslim Society, Vol. 1, No. 1 (Juni 2014): 13-33.

${ }^{11}$ Abu Darda, "Integrasi Ilmu dan Agama: Perkembangan Konseptual di Indonesia," Jurnal At-Ta'dib, Vol. 10, No. 1 (Juni 2014): 33-46.

${ }_{12}$ Mohammad Muslih, "Tren Pengembangan Ilmu di UIN Sunan Kalijaga Yogyakarta," Episteme: Jurnal Pengembangan Ilmu Keislaman, Vol. 12, No. 1 (Juni 2017): 103-139

${ }^{13}$ Anshori dan Zainal Abidin, "Format Baru Modern Hubungan Sains dan Islam: Studi Integrasi Keilmuan atas UIN Yogyakarta, dan Tiga Universitas Islam Swasta Sebagai Upaya Membangun Islam Seutuhnya Tahun 2007-2013," Profetika: Jurnal Studi Islam, Vol. 15, No. 1 (Juni 2014): 90-108.

${ }^{14}$ Waryani Fajar Riyanto, Integrasi Interkoneksi Keilmuan Biografi Intelektual M. Amin Abdullah (1953....): Person, Knowledge, and Institution (Yogyakarta: Suka Press, 2013).

${ }^{15}$ Afiful Ikhwan, "Perguruan Tinggi Islam dan Integrasi Keilmuan Islam," At-Tajdid: Jurnal Ilmu Tarbiyah, Vol. 5, No. 2 (Juni 2016): 159-187.

${ }^{16}$ Luthfi Hadi Aminuddin, "Integrasi Ilmu dan Agama: Studi atas Paradigma IntegratifInterkonektif UIN Sunan Kalijaga Yogyakarta," Kodifikasia: Jurnal Penelitian Keagamaan dan Sosial Budaya, Vol. 4, No. 1 (Juni 2010): 181-214. 
UIN Maliki dalam pembahasannya seperti kajian yang dilakukan oleh Husniyatus Salamah Zainiyati, ${ }^{17}$ dan Moh. Yunus. ${ }^{18}$ Selain itu, kajian yang mencantumkan konsep integrasi di UIN Sunan Kalijaga dan UIN Maliki menjadi pembahasan khusus sekaligus seperti karya Anshori ${ }^{19}$ dan Moch. Khafidz Fuad Raya. ${ }^{20}$

Dari jejeran kajian di atas, yang paling mendekati kajian ini adalah tulisan Anshori dan Moch. Khafidz Fuad Raya. Hanya saja, kajian mereka lebih berorientasi pada penjelasan secara umum dan komparasi terkait Spider Web dan Syajarh al-'Ilm dan tidak menyentuh langsung pada integrasi hadis dan ilmu yang ada dalam kedua konsep tersebut. Kajian ini pun tidak akan terfokus pada konsep Spider Web dan Shajarah al-'Ilm, tetapi akan terfokus pada posisi hadis dalam kedua konsep dan realisasinya dalam kajian-kajian dosen di lingkungan kampus masing-masing. Dengan demikian, kajian mengenai hadis integratif di kedua konsep tersebut memiliki nilai kebaruan dalam konteks akademis.

Kajian ini pun merupakan kelanjutan dari kajian-kajian yang telah dilakukan oleh penulis sebelumnya. Dalam konteks ini, telah terbit beberapa karya yang berkenaan dengan dengan tema integrasi hadis dan ilmu, yaitu "Membangun Integrasi Ilmu-Ilmu Sosial dan Hadis Nabi" yang terbit di Jurnal Living Hadis (2016), "Memahami Eksistensi Pendekatan Ilmu-Ilmu Alam dan Pemahaman Hadis Nabi" yang terbit dalam buku Membangun Kembali Peradaban Islam Prestisius (2016), ${ }^{22}$ dan Integrasi Ilmu-Ilmu Alam dan Ilmu-Ilmu Sosial dengan Pemahaman Hadis Nabi: Telaah atas Konsepsi, Aplikasi, dan Implikasi yang terbit di Jurnal Theologia (2017). ${ }^{23}$

\section{PEMBAHASAN}

\section{Hadis dalam Konsep Spider $W e b$}

\section{Spider Web sebagai Identitas UIN Sunan Kalijaga Yogyakarta}

UIN Sunan Kalijaga menelurkan istilah khusus untuk penyatuan agama dan ilmu, yakni integrasi dan interkoneksi. Dua istilah inilah yang menjadi ciri khas

17 Husniyatus Salamah Zainiyati, "Landasan Fondasional Intergasi Keilmuan di UIN Maulana Malik Ibrahim Malang dan UIN Sunan Ampel Surabaya," Islamica: Jurnal Studi Keislaman, Vol. 10, No. 1 (Juni 2015): 248-276; Husniyatus Salamah Zainiyati, "Model Kurikulum Integratif Pesantren Mahasiswa dan UIN Maliki Malang," Ulumuna: Jurnal Studi Keislaman, Vol. 18, No. 1 (Juni 2014): 139-158.

18 Moh. Yunus, "Integrasi Agama dan Sains: Merespon Kelesuan Tradisi Ilmiah di PTAI," Insania: Jurnal Pemikiran Alternatif Kependidikan, Vol. 19, No. 2 (Desember 2014): 284-313.

19 Anshori," Integrasi Keilmuan atas UIN Jakarta, UIN Yogyakarta, dan UIN Malang" (Disertasi: Pascasarjana UIN Sunan Kalijaga Yogyakarta, 2014).

20 Moch. Khafidz Fuad Raya, "Model Pengembangan Keilmuan UIN Malang dan UIN Jogjakarta," Falasifa: Jurnal Ilmu Keislaman, Vol. 8, No. 1 (Juni 2017): 65-82.

${ }^{21}$ Benny Afwadzi, "Membangun Integrasi Ilmu-Ilmu Sosial dan Hadis Nabi," Jurnal Living Hadis, Vol. 1, No. 1 (Juni 2016): 101-127.

22 Benny Afwadzi, "Memahami Eksistensi Pendekatan Ilmu-Ilmu Alam dan Pemahaman Hadis Nabi" dalam Membangun Kembali Peradaban Islam Prestisius (Malang: UIN Maliki Press, 2016), 69-109.

${ }^{23}$ Benny Afwadzi, "Integrasi Ilmu-Ilmu Alam dan Ilmu-Ilmu Sosial dengan Pemahaman Hadis Nabi: Telaah atas Konsepsi, Aplikasi, dan Implikasi," Jurnal Theologia, Vol. 28, No. 2 (Desember 2017): 351-390. 
pengembangan keilmuan yang dicanangkan oleh kampus ini. Secara sistemik, kajian-kajian keilmuan berpijak pada prinsip integrasi-interkoneksi tersebut. Dua kata ini meskipun bersandingan, namun mempunyai arti yang berlainan dalam tradisi akademik. Yang dimaksud integrasi adalah "menghubungkan dan sekaligus menyatukan antara dua hal atau lebih (materi, pemikiran, atau pendekatan)," sedangkan interkoneksi ialah "mempertemukan atau menghubungkan dua hal atau lebih (materi, pemikiran, atau pendekatan) karena tidak mungkinnya untuk dilakukan penyatuan (integrasi)." Dengan demikian, integrasi-interkoneksi merupakan upaya menghubungkan, mengaitkan, atau bahkan juga menyatukan berbagai macam keilmuan. ${ }^{24}$

Supaya lebih mudah dimengerti, uraian Syamsul Anwar, salah seorang intelektual asal UIN Sunan Kalijaga dapat diketengahkan untuk menjelaskan maksud integrasi dan interkoneksi tersebut. Menurutnya, integrasi dan interkoneksi mempunyai dua makna yang terpisah. Sisi yang membedakan keduanya adalah adanya terjadi restrukturisasi keilmuan atau tidak. Dalam integrasi, restrukturisasi ini terjadi berdasarkan prinsip-prinsip tertentu, yang berimplikasi pada perubahanperubahan atas paradigma, teori, metode, dan prosedur-prosedur teknis dalam sebuah bidang ilmu. Sementara itu, interkoneksi tidak mengenal adanya restrukturisasi seperti itu, yang terjadi adalah perluasan perspektif dengan menyerap informasi komplemen dari bidang ilmu lainnya. Oleh karenanya, interkoneksi dirumuskan oleh Syamsul sebagai "Proses pengkajian dalam suatu bidang ilmu dengan memanfaatkan data dan analisis dalam ilmu lain terkait di samping menggunakan data dan analisis ilmu bersangkutan sendiri dalam rangka komplementasi, konfirmasi, kontribusi, atau komparasi (4k)." ${ }^{25}$

Dengan kata lain, integrasi mengendaki adanya peleburan beberapa ilmu menjadi sebuah kategori ilmu baru, misalnya contoh yang diketengahkan Syamsul adalah ilmu ekonomi Islam. Ilmu ini merupakan restrukturisasi pada ilmu ekonomi konvensional berdasarkan prinsip-prinsip yang ada dalam syariah. ${ }^{26}$ Sedangkan intekoneksi dilakukan dengan mendudukan dua aspek, yakni "objek material" dan "objek formal." Objek material dikaji dengan objek formal yang menjadi pendekatannya. Kajian ilmu hadis dengan ilmu astronomi yang dilakukan Syamsul, misalnya, termasuk kategori interkoneksi, sebab mengetengahkan ilmu hadis sebagai objek materialnya dan ilmu astronomi sebagai objek formalnya.

Spider Web tidak bisa terlepas dari figur pencetusnya, yakni M. Amin Abdullah yang pernah menjadi Rektor UIN Sunan Kalijaga selama dua periode (2001-2005 dan 2006-2010). Ia mempunyai posisi penting dalam pembangunan corak keilmuan di UIN Sunan Kalijaga Yogyakarta. Kedudukannya laksana "Nabi" yang dimiliki oleh institusi ini dan belum tergantikan hingga kini. Namun sebelum membahas Spider Web yang digagas oleh Amin, perlu diawali dengan kajian tentang triadik keilmuan integrasi-interkoneksi UIN Sunan Kalijaga yang juga

${ }^{24}$ Mohammad Muslih, "Tren Pengembangan Ilmu di UIN Sunan Kalijaga Yogyakarta," Episteme: Jurnal Pengembangan Ilmu Keislaman, Vol. 12, No. 1 (Juni 2017) 111.

25 Syamsul Anwar, Interkoneksi Studi Hadis dan Astronomi (Yogyakarta: Suara Muhammadiyah, 2011), 2-3.

${ }^{26}$ Syamsul Anwar, Interkoneksi Studi Hadis dan Astronomi, 2. 
diinisiasi oleh Amin berupa tiga peradaban (hadhärah) yang saling terkait satu sama lain, yang disebut Waryani Fajar Riyanto, "juru bicara" pemikiran M. Amin Abdullah, sebagai "mazhab Jogja." 27 Ketiga peradaban yang dimaksud adalah hadhärah al-nashsh (peradaban teks normatif), hadhärah al- 'ilm (peradaban ilmu pengetahuan empiris), dan hadhārah falsafah (peradaban filsafat herrmeneutis). Ketiganya menjadi keilmuan yang identik dengan UIN Sunan Kalijaga.

Mengenai hubungan triadik antara ḥadhārah al-nashsh, hadhärah al- 'ilm, dan hadhārah falsafah, paling tidak terdapat tiga skema sebagaimana disampaikan Amin. Pertama, skema single entity (entitas tunggal), yang berupa klaim bahwa keilmuannya sendiri sudah cukup untuk menyelesaikan permasalahan yang ada. Model ini bisa hanya diisi oleh hadhārah al-nashsh saja, hadhārah al-'ilm saja, atau juga hadhārah falsafah saja. Model berpikir seperti ini menyimbolkan keangkuhan ilmu pengetahuan. Kedua, skema isolated entities (entitas yang terisolasi), yang memperlihatkan kemajuan dunia akibat adanya ketiga entitas keilmuan tersebut, baik hadhārah al-nashsh, ḥadhārah al-'ilm, maupun ḥadhārah falsafah. Namun, konfigurasi hubungan yang ada ternyata terisolasi satu dengan lainnya sehingga menimbulkan permasalahan dunia kontemporer. Ketiga, skema interconnected entities (entitas yang terkoneksi), yang berupa adanya kesadaran dari masingmasing kelimuan bahwa mereka mempunyai kelemahan sendiri-sendiri. Oleh sebab itu, mereka bersedia untuk berdialog, bekerja sama, memanfaatkan metode dan pendekatan yang digunakan oleh rumpun pengetahuan lain untuk melengkapi kekurangan tersebut. Lebih tegasnya, antara hadhärah al-nashsh, hadhärah al-'ilm, dan hadhārah falsafah terjadi interkoneksitas satu dengan lainnya. Menurut Amin, skema ketiga inilah yang cocok diterapkan di Universitas Islam Negeri, dan diaplikasikan di UIN Sunan Kalijaga Yogyakarta. ${ }^{28}$

Dalam konsepsi triadik keilmuan di atas, fungsi adanya hadhārah falsafah adalah sebagai jembatan penghubung antara ḥadhärah al-nashsh dan ḥadhārah al'ilm. Ia bertindak sebagai pelerai atau setidaknya menjernihkan bercampurnya dimensi doktrinal-teologis dan kultural-historis yang ada dalam benak pembaca. ${ }^{29}$ Agaknya keilmuan filsafat sebagai bidang kajian yang digeluti oleh Amin membentuk pandangan spesialnya pada ilmu tersebut. Sejak awal, ia memang menaruh perhatian khusus pada filsafat yang seharusnya digunakan membaca ilmuilmu keagamaan, oleh karenanya ia sampai menyebut filsafat ilmu sebagai perangkat analisis yang terlupakan (the forgotten analitical tool) dalam tulisannya

${ }^{27}$ Waryani Fajar Riyanto, Mazhab Sunan Kalijaga: Setengah Abad Genealogi Epistemologi Studi Hukum Islam Integratif di Fakultas Syari'ah dan Hukum UIN Sunan Kalijaga Yogyakarta (19632013 M/1383-1433 H) (Yogyakarta: Fakultas Syari'ah dan Hukum UIN Sunan Kalijaga Yogyakarta dengan Kurnia Kalam Semesta, 2014), 377.

28 M. Amin Abdullah, Islamic Studies di Perguruan Tinggi: Pendekatan IntegratifInterkonektif (Yogyakarta: Pustaka Pelajar, 2012), 404-405.

29 Muhammad Alfatih Suryadilaga, "Ragam Studi Hadis di PTKIN Indonesia dan Karakteristiknya: Studi atas Kurikulum IAIN Bukittinggi, IAIN Batusangkar, UIN Sunan Kalijaga, dan IAIN Jember," Journal of Qur'an and Hadith Studies, Vol. 4, No. 2 (Desember 2015): 235. 
di jurnal al-Jami'ah tahun $2003 .{ }^{30}$ Secara lebih jelas, hubungan ketiganya serta fungsinya dapat digambarkan sebagai berikut: ${ }^{31}$

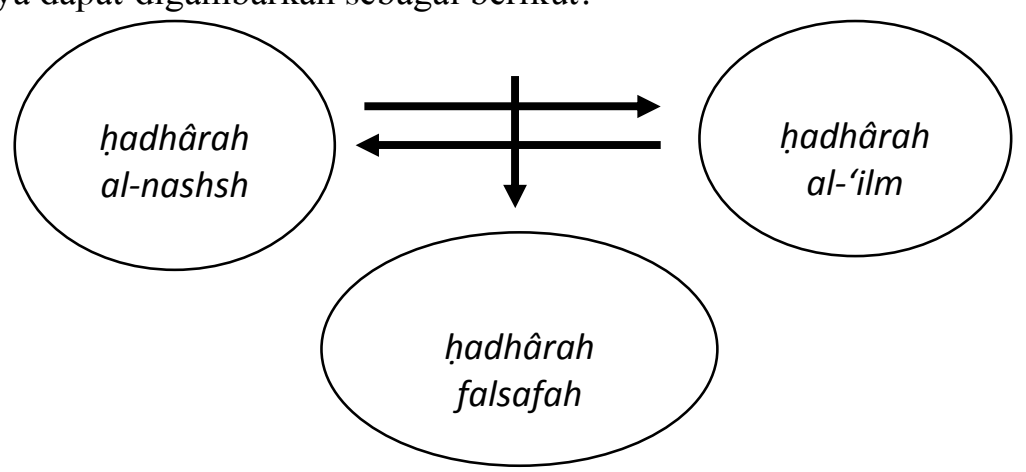

Gambar 1: Skema Hubungan tiga ḥadhārah

Setelah berbicara tentang integrasi-interkoneksi, maka sudah saatnya menjelaskan mengenai Spider Web yang menjadi identitas UIN Sunan Kalijaga Yogyakarta. Spider Web merupakan sebuah metafora pengembangan akademik di UIN Sunan Kalijaga. Dalam konsep ini, pada bagian inti terdapat Alquran dan Sunnah sebagai sentralnya, yang kemudian dikembangkan melalui proses ijtihad dengan memakai berbagai pendekatan (approach) dan metodologi (methodology). Proses seperti ini lantas memberikan inspirasi bagi munculnya ilmu-ilmu keislaman klasik, yaitu tafsir, lughah, kalam, falsafah, tasawuf, hadis, tarikh, dan fiqih. Melalui proses yang sama, pada abad-abad berikutnya lahir ilmu-ilmu kealaman, sosial, dan juga humaniora, dan kemudian berujung pada munculnya ilmu-ilmu dan isu-isu kontemporer di lapis selanjutnya. Pada lapis ilmu alam, sosial, dan humaniora terdapat ilmu hermeneutika, filologi, biologi-kimia, etika, fenomenologi, psikologi, filsafat, sejarah, antropologi-sosiologi, arkeologi, dan matematika-fisika. Sementara itu, pada lapis ilmu-ilmu dan isu-isu kontemporer memuat pluralisme agama, ilmu pengetahuan dan teknologi, ekonomi, Hak Asasi Manusia, politik/masyarakat madani, budaya (studi budaya), isu-isu gender, isu-isu lingkungan, dan hukum internasional. Berbagai macam keilmuan tersebut, dalam integrasi-interkoneksi, saling berinteraksi dan berdialog satu dengan yang lain, sehingga tidak dikenal lagi adanya dikotomi keilmuan. ${ }^{32}$

30 M. Amin Abdullah, "New Horizons of Islamic Studies Through Socio-Cultural Hermeneutics," al-Jāmi'ah: Journal of Islamic Studies, Vol. 41, No. 1 (2003): 9-14.

${ }^{31}$ Skema ini dibuat sendiri oleh penulis yang berbeda dengan penggambaran Amin dengan pertimbangan untuk lebih memahamkan dengan yang diinginkan oleh fungsi ketiganya.

${ }^{32}$ M. Amin Abdullah dkk., Kerangka Dasar Keilmuan dan Pengembangan Kurikulum Universitas Islam Negeri (UIN) Sunan Kalijaga Yogyakarta (Yogyakarta: Pokja Akademik UIN Sunan Kalijaga, 2006), 21. 


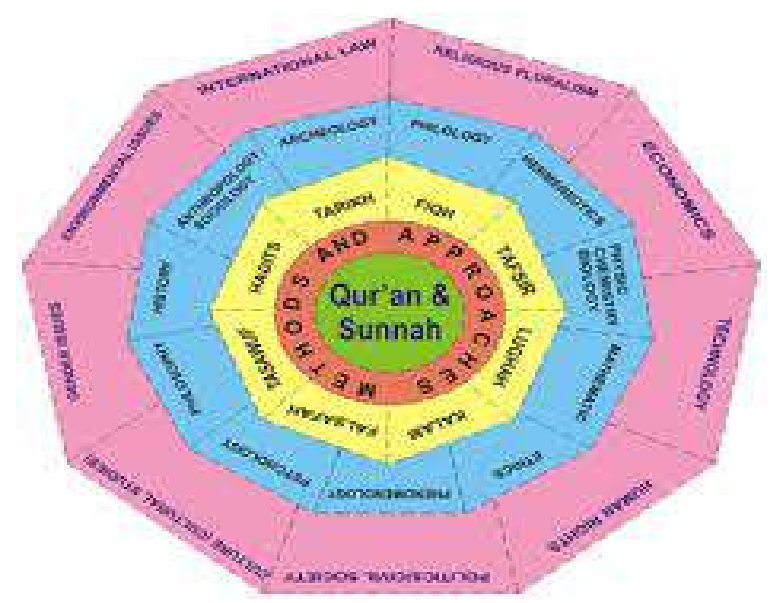

Gambar 2: Spider Web

Dalam metafora jaring laba-laba di atas, terdapat garis putus-putus dan menyerupai pori-pori yang melekat di dinding pemisah antar berbagai keilmuan yang ada di dalamnya. Menurut Amin, dinding tersebut tidak hanya diartikan dengan batasan antar disiplin ilmu, melainkan juga dengan batasan ruang dan waktu, cara berpikir (worldview), dan 'urf(custom) dalam tradisi keislaman, yaitu corak dan budaya berpikir pada masa klasik, pertengahan, modern, dan juga postmodern. Pori-pori laksana lubang ventilasi di dinding yang berfungsi sebagai pengatur sirkulasi udara yang masuk dan keluar dan jalan pertukaran informasi antar keilmuan. Masing-masing disiplin keilmuan, dan juga cara pandang, budaya berpikir, tradisi atau 'urf yang menyertainya, dapat secara bebes berkomunikasi satu dengan lainnya, terlibat dalam dialog, menembus untuk mengirimkan pesan dan masukan temuan-temuan yang baru di bidangnya pada bidang-bidang ilmu lainnya. Terdapat kondisi bebas, nyaman, dan tanpa beban dalam pertukaran informasi antar keilmuan tersebut. ${ }^{33}$

Meskipun demikian, bagi Amin, dalam Spider Web, masing-masing bidang ilmu masih dapat mempertahankan identitas dan eksistensinya sendiri, hanya saja terdapat ruang terbuka untuk dialog, komunikasi, dan diskusi dengan disiplin ilmu lain. Diskusi terjadi tidak hanya pada ilmu-ilmu secara internal, seperti fisika dan matematika (natural sciences), akan tetapi juga bersedia dan dapat berdiskusi dan menerima masukan dari pengetahuan eksternal, seperti ilmu-ilmu sosial-humaniora (social sciences-humanities). Mekanisme ini juga terjadi pada ranah ilmu-ilmu agama yang dalam Spider Web berada di kluster ketiga. Tidak ada ilmu yang menutup dirinya sendiri dan membatasi dirinya secara ketat. Memang batasan itu ada seperti tergambar dalam Spider $W e b$, namun batasan tersebut tidak kemudian kedap sinar dan suara. Dalam hal ini, pori-pori yang melekat pada dinding pembatas dapat dipengaruhi dan ditembus oleh disiplin ilmu lain. ${ }^{34}$

33 M. Amin Abdullah, "Religion, Science and Culture; An Integrated, Interconnected Paradigm of Science," 182.

34 M. Amin Abdullah, "Religion, Science and Culture; An Integrated, Interconnected Paradigm of Science," 182-183. 
Sebenarnya, Spider Web yang digagas oleh Amin sangat berkaitan dengan istilah-istilah yang sering diungkapkannya dalam berbagai kesempatan, yakni 'Ulūm al-Dīn (ilmu-ilmu agama), al-Fikr al-Islāmì (pemikiran Islam), dan Dirāsat Islämiyah (studi Islam). ${ }^{35}$ Secara eksplisit dalam tulisannya, ia mengatakan mengenai ketiga istilah ini:

“"Ulüm al-Dīn sebagai representasi "tradisi lokal" keislaman yang berbasis pada "bahasa" dan "teks-teks" atau nash-nash keagamaan, al-Fikr al-Islämíy sebagai representasi pergumulan humanitas pemikiran keislaman yang berbasis pada "rasiointelek", sedangkan Dirāsat Islämiyah at au Islamic Studies sebagai kluster keilmuan baru yang berbasis pada paradigma keilmuan sosial kritis-komparatif lantaran melibatkan seluruh "pengalaman" (experiences) umat manusia di alam historisempiris yang amat sangat beranekaragam." 36

Dalam konteks ini, 'Ulüm al-Dīn (sesuai istilah Imam al-Ghazāii) atau Religious Knowledge berada dalam lapisan ketiga dalam konsep Spider Web di atas (warna kuning), yang meliputi hadith, tarikh, fiqih, tafsir, lughah, kalam, falsafah, dan tasawuf. Lapisan ini merupakan tradisi keilmuan Islam yang berbasis pada bahasa dan teks-teks keagamaan (Alquran dan hadis). Amin Abdullah menyebut pula untuk lapisan ini sebagai hadhārah al-nashsh, sedang Muhammad 'Ābid alJābirì, seorang pemikir Muslim asal Maroko membahasakannya dengan bayāni $\bar{i}^{37}$ Kategori ilmu di lapisan ini juga sering disebut sebagai turāth.

Sementara itu, al-Fikr al-Islämi atau pemikiran Islam merupakan pergumulan humanitas pemikiran yang berpijak pada rasionalitas. Al-Jābirī menyebut keilmuan ini dengan istilah burhānî. Adapun Dirāsat Islämiyah adalah kluster keilmuan baru yang berbasis pada paradigma keilmuan sosial kritis-komprehensif karena melibatkan seluruh pengalaman manusia di alam historis-empiris yang sangat beranekaragam. Bagi Amin, banyak kalangan yang belum dapat membedakan antara ketiganya secara jelas dan gamblang, mana yang masuk 'Ulüm al-Dinn, maka yang masuk al-Fikr al-Islämî, dan mana yang masuk Dirāsat Islämiyah. Berbekal permasalahan ini, Amin pun membuat simplikasi tiralektis ketiganya dengan wujud Spider Web. ${ }^{38}$

\section{Hadis Nabi dalam Spider Web}

Terkait dengan model triadik keilmuan di UIN Sunan Kalijaga, dapat dipahami bahwa disiplin ilmu hadis yang telah dirancang oleh para ulama merupakan hadhärah al-nashsh yang perlu didialogkan dengan hadhärah al-'ilm berupa beberapa varian keilmuan lain, yaitu ilmu-ilmu alam (natural sciences),

35 M. Amin Abdullah, "Mempertautkan Ulum al-Diin, al-Fikr al-Islamiy dan Dirasat Islamiyyah: Sumbangan Keilmuan Islam untuk Peradaban Global" dalam https://aminabd.wordpress.com (10 Juni 2010), diakses 11 Nopember 2018.

36 M. Amin Abdullah, "Mempertautkan Ulum al-Diin, al-Fikr al-Islamiy dan Dirasat Islamiyyah: Sumbangan Keilmuan Islam untuk Peradaban Global" dalam https://aminabd.wordpress.com (10 Juni 2010), diakses 11 Nopember 2018.

${ }^{37}$ Waryani Fajar Riyanto, Mazhab Sunan Kalijaga, 179.

38 Waryani Fajar Riyanto, Mazhab Sunan Kalijaga, 179. 
ilmu-ilmu sosial (social sciences) dan ilmu-ilmu humaniora (humanities). Adanya dialog antara kedua jenis peradaban tersebut lantas dijembatani oleh keilmuan filsafat sebagai hadhārah falsafah-nya supaya tidak terjadi kesewenang-wenangan interpretasi hadis dan pendewaan subjektifitas. Dalam konteks ini, harus disadari bahwa dalam ilmu hadis mempunyai kelemahan dan harus berikan sentuhan ilmuilmu lain agar bisa melengkapi kekurangan tersebut.

Sebenarnya, problem utama dalam proses integrasi adalah memang mudah mencocok-cocokkan antara hadis dengan sains tanpa memandang secara filosofis ketepatan maknanya, atau dengan bahasa populis: asal gotak-gatik-gatok. Jika hal seperti ini dibiarkan, maka dapat dimungkinkan terjadi "pemaksaan" terhadap hadis itu sendiri, hadis dipaksa-paksa untuk berbicara tentang sains yang dikehendaki. Padahal dalam pemahaman hadis, diperlukan makna yang mendekati tradisi kenabian, dan bukan asal-asalan "mencomot" hadis. Sebagian karya yang mengklaim sebagai karya integrasi, disadari atau tidak, hanya berdasarkan ilmu "cocoklogi" semata. Atau dengan arti lain, setelah menjelaskan konsep tertentu dalam sebuah bidang ilmu, lantas dicari justifikasinya dalam teks hadis atau sekedar mencantumkan hadis sebagai bukti integrasinya tanpa diidentifikasi secara filosofis terlebih dahulu apakah tepat maknanya seperti itu. Adanya pengutipan hadis dalam karyanya dianggap memperkuat konsepsi yang telah dibangun sebelumnya sekaligus dianggap telah melaksanakan integrasi agama dan ilmu pengetahuan.

Padahal, mengaitkan antara hadis dan ilmu pengetahuan harus dilakukan dengan pemikiran mendalam, dan bukan asal dikaitkan saja. Hal ini dikarenakan hadis berasal dari abad ketujuh masehi dan ilmu pengetahuan berasal dari pergulatan pemikiran manusia di era modern dan post-modern. Mereka berasal dari dua waktu yang berlainan. Meskipun hadis dikonsepsikan sebagai wahyu yang tidak terucap (ghayr al-matluw) oleh sebagian ulama yang pasti menyimpan aspek-aspek kemu'jizatan dari Allah, ${ }^{39}$ namun sebagian darinya berasal dari diri Nabi Muhammad sendiri sebagai figur bangsa Arab yang hidup pada abad ketujuh masehi. Sehingga, apa yang dikatakan oleh beliau, secara antroplogis-sosiologis, terkadang sangat berkaitan erat dengan kondisi keilmuan dan sosial-budaya pada masa itu, dan ini terbukti dengan kesalahan Nabi dalam peristiwa penyerbukan kurma di Madinah..$^{40}$ Maka, di sinilah keilmuan filsafat yang disebut Amin dengan hadhärah falsafah menempati posisi sentralnya.

Istilah integrasi dan interkoneksi mempunyai dampak yang berlainan. Integrasi memuat adanya restrukturisasi atau secara gampangnya terjadi peleburan pada aspek objek materialnya. Objek material dalam ilmu hadis dan ilmu-ilmu lain lebur menjadi sebuah bahasan tersendiri yang agak berbeda dari wujud awalnya.

${ }^{39}$ Muḥammad 'Ajjaj al-Khâtib, Ushâl al-Hadîts 'Ulûmuhu wa Mushthalâhuhu (Beirut: Dâr Fikr, 1989), 35; Abû Hâmid al-Ghazâlî, al-Mustashfâ min 'Ilm al-Ushûl (Beirut: Dâr Kutub Ilmiyah, 2010), 170.

${ }^{40}$ Benny Afwadzi "Memahami Eksistensi Pendekatan Ilmu-Ilmu Alam dan Pemahaman Hadis Nabi" dalam Membangun Kembali Peradaban Islam Prestisius (Malang: UIN Maliki Press, 2016), 74-81. 
Dalam kajian hadis, integrasi ini terjadi, seperti diskursus kepemimpinan profetik yang berarti teori-teori kepemimpinan yang diadaptasi dari ajaran-ajaran Nabi dalam hadis. Begitu pula misalnya, metodologi berpikir profetik yang merupakan cara berpikir berdasarkan prinsip-prinsip dalam hadis Nabi. Yang terbaru dan menjadi kajian yang banyak diperhatikan sekarang ini adalah living hadis, yaitu ilmu hadis yang melebur bersama ilmu sosial, yang diinisiasi oleh dosen-dosen Tafsir Hadis UIN Sunan Kalijaga. Sementara itu, interkoneksi terjadi ketika terjadi dialog dengan ilmu lain sebagai objek formalnya (pendekatan). Misalnya, kajian terhadap hadis-hadis yang berhubungan dengan astronomi yang dikaji dengan pendekatan ilmu astronomi; hadis-hadis tentang sosial-kemasyarakatan ditelaah dengan pendekatan ilmu sosiologi-antropologi dan hermeneutika; dan hadis-hadis yang berhubungan dengan kondisi geografis Nabi dikaji dengan ilmu geografi. Kajian interkoneksi merupakan studi yang paling digandrungi di kalangan pengkaji hadis di lingkungan UIN Sunan Kalijaga.

Syamsul Anwar menyebutkan ada empat pola dalam interkoneksi yang dapat dilakukan oleh pemikir Muslim, khususnya pengkaji hadis yang diistilahkan olehnya dengan " $4 \mathrm{k}$." Pertama, komplementasi, berupa adanya data dan temuan ilmu yang menjadi pendekatan bisa melengkapi data dan analisis dalam ilmu yang menjadi objek material, sehingga sangat dimungkinkan mengambil kesimpulan yang lebih valid. Kedua, konfirmasi, yaitu ilmu yang dipakai sebagai pendekatan mampu memperkuat hasil temuan dalam ilmu yang menjadi objek material. Ketiga, kontribusi, yang berarti ilmu yang menjadi objek formal bisa menyumbangkan temuan-temuan yang dapat mempertajam temuan dalam ilmu objek material. Keempat, komparasi, yakni hasil-hasil analisis ilmu-ilmu tertentu bisa menjadi pembanding bagi ilmu objek material dalam rangka memperluas cakrawala pengetahuan. ${ }^{41}$

Dalam konsep Spider Web, sunnah diletakkan dalam posisi sentral di tengah yang menandakan bahwa ilmu apapun tidak dapat melepaskan keberadaan sumber kedua dalam Islam tersebut. Namun selain itu, muncul pula istilah hadith pada kluster ketiga. Mungkin ada yang bertanya, dalam konsep Spider Web sudah disebutkan sunah dalam intinya, lantas mengapa disebutkan kembali dengan nama hadith dalam lapisan ketiga ( 'Ulüm al-Dīn, bayānīi)? Dalam memahami ini, harus dipahami dulu bahwa sunah yang berada di inti, yang bersandingan dengan Alquran, merupakan sunah dalam arti normatifnya, yakni sunah sebagai tradisi kenabian yang berasal dari Muhammad yang terpresentasikan dalam wujud teks hadis. Oleh sebab itu, ia bersanding dengan Alquran yang juga merupakan teks normatif keagamaan. Sementara dalam lapisan ketiga, diskursus yang dimunculkan tidak hanya berbentuk sunah dan wujud teks saja, akan tetapi teks tersebut dikaji dan dijadikan acuan dalam praktik kehidupan, sehingga memunculkan bagianbagian dari ilmu hadis yang bermacam-macam, mulai dari kritik sanad dan matan yang melahirkan pembagian status hadis shahih, hasan, dhaif, dan palsu maupun syarah hadis yang membentuk bagaimana cara memahami hadis. Dimensi ini sudah

${ }^{41}$ Syamsul Anwar, Interkoneksi Studi Hadis, 3-4. 
masuk pada wilayah historis dari hadis Nabi, dan membentuk keilmuan yang bernama hadith.

Dalam Spider Web, hadis Nabi tidak bisa dikaji dengan warisan ilmu Islam klasik an sich, akan tetapi harus pula bertemu dan saling melengkapi dengan ilmuilmu yang muncul di era modern, baik ilmu alam, sosial, humaniora, dan bahkan isu-isu kontemporer. Beberapa keilmuan di kluster selanjutnya yang biasa digunakan dalam mengkaji hadis adalah sejarah, antropologi-sosiologi, sejarah, semiotika, dan hermeneutika. Penggunaan ilmu-ilmu tersebut lebih banyak disukai civitas akademika UIN Sunan Kalijaga. Maklum saja, pemikiran Islam di kampus ini boleh dikatakan sangat mengakar kuat seiring dengan usianya yang sudah sangat tua, sehingga pengembangannya diarahkan pada interaksi dengan keilmuan sosial-humaniora. Di kampus ini, fakultas yang menaungi jurusan Ilmu Hadis pun bernama Fakultas Ushuluddin dan Pemikiran Islam, yang dahulunya hanya bernama Ushuluddin.

Dalam konteks ini, jurusan Tafsir Hadis, yang sekarang dipisah menjadi Ilmu Alquran dan Tafsir (IAT), dan Ilmu Hadis (ILHA) sesuai Putusan Menteri Agama (PMA) oleh Dirjen Pendis nomor 1429 tahun 2012, ${ }^{42}$ merupakan jurusan yang mengkaji secara langsung berbagai persoalan hadis. Ia mempunyai posisi sentral dalam bangunan keilmuan hadis integratif Spider Web di UIN Sunan Kalijaga. Di dalamnya, kajian-kajian integratif menemukan porsinya secara signifikan dan mempertimbangkan berbagai kemungkinan yang ada, baik secara keilmuan hadis klasik maupun kontemporer. Tanpa adanya jurusan Tafsir Hadis (atau ILHA) tidak akan mungkin interkoneksi hadis dengan ilmu-ilmu lainnya secara filosofis dapat digerakkan secara massal. Jurusan ini adalah yang mengaktualisasikan secara langsung bagaimana ilmu hadis dikaji dengan pendekatan keilmuan alam, sosial, maupun humaniora.

Spider Web menghendaki adanya integrasi kurikulum dalam pengkajiannya. Dalam jurusan Ilmu Hadis Fakultas Ushuluddin dan Pemikiran Islam UIN Sunan Kalijaga misalnya, beberapa mata kuliah sudah terintegrasi-terinterkoneksi dengan disiplin ilmu alam, sosial, dan juga humaniora. Mata kuliah-mata kuliah integratif ini ada sebagai manifestasi prinsip integrasi-interkoneksi keilmuan. Beberapa mata kuliah tersebut adalah studi shoftware hadis, hadis hukum dan sosial, sejarah dan dinamika sosial hadis, hadis sains, hadis dan media, ma'anil hadis, living hadis, hadis dan difabilitas, kajian hadis berbasis tekonologi informatika, dan studi manuskrip hadis. $^{43}$ Belum lagi saat semester-semester awal, mahasiswa diperkenalkan dengan mata kuliah-mata kuliah dari cabang ilmu sosial-humaniora lain, seperti filsafat ilmu dan pengantar sosiologi-antropologi.

Penampakan mata kuliah dengan format seperti di atas sesuai dengan pemikiran Amin, sang penggagas Spider Web. Menurut Amin, Fakultas Tarbiyah, Dakwah, Adab, dan Ushuluddin harus memuat ilmu-ilmu sosial seperti sosiologi dan antropologi agama, serta ilmu humaniora kontemporer misalnya Teologi

${ }^{42}$ Suryadi, "Prospek Studi Hadis di Indonesia (Telaah atas Kajian Hadis di UIN, IAIN, dan STAIN)," Jurnal Studi Ilmu-Ilmu Al-Qur'an dan Hadis, Vol. 16, No. 1 (2015): 1-16.

${ }^{43}$ Muhammad Alfatih Suryadilaga, "Ragam Studi Hadis", 222. 
Pembebasan, HAM dalam Islam, isu gender, etika, sejarah ilmu pengetahuan, filsafat ilmu pengetahuan, dan lain sebagainya. Hal yang sama juga hendaknya dilaksanakan di Fakultas Sains dan Teknologi dan Fakultas Sosial-Humaniora. Fakultas Syariah juga tidak boleh menolak mata kuliah yang mengandung ilmu humaniora kontemporer dan ilmu sosial, seperti hermeneutika, cultural dan religious studies, HAM, sensivitas gender, filsafat ilmu, dan lain sebagainya. ${ }^{44}$

\section{Implementasi Konsep Spider Web ke dalam Karya-Karya Dosen}

Sebagai implementasi konsep integrasi terdapat karya Musa Asy'arie, Rektor UIN Sunan Kalijaga tahun 2010-2014, yang berjudul Rekonstruksi Metodologi Berpikir Profetik Perspektif Sunnah Nabi. Dalam buku ini, Musa melakukan integrasi antara metodologi berpikir dengan sunah Nabi. Ia ingin menawarkan gagasan berpikir ala Nabi Muhammad, yang sebelumnya dianggap kurang mendapatkan perhatian. Hal ini barangkali disebabkan rujukan berpikir dipandang tidak dijelaskan dalam risalah kenabian, atau juga karena bagaimana Nabi Muhammad berpikir jarang dijadikan objek kajian yang mendalam. ${ }^{45}$ Dalam menguraikan argumennya, Musa mengutip ayat-ayat Alquran yang jumlahnya banyak sekali, sejarah kenabian, dan hadis Nabi juga.

Aliran pemikiran yang ada di dunia, menurut Musa, terbagi atas dua tipologi, yakni pemikiran Barat dan pemikiran Timur. Pemikiran Barat digambarkan sebagai pemikiran yang rasional dan bebas, sedangkan pemikiran Timur disebutkan sebagai pemikiran yang rasional-doktrinal. Dengan maksud lain, pemikiran Barat mengandalkan kekuatan rasio semata, sementara pemikiran Timur mengandalkan kekuatan non-rasio berupa kepercayaan dan hal-hal yang bersifat ghaib, meskipun corak keduanya bukanlah sesuatu yang bersifat mutlak. ${ }^{46}$ Dengan adanya kenyataan itu, kiranya penting untuk mengetahui cara berpikir yang sesuai dengan sunah Nabi, sang panut an hidup.

Musa menyatakan bahwa berpikir kenabian merupakan cara berpikir guna mendapatkan hikmah dengan metode rasional trasendental. Metode ini adalah suatu pemikiran yang mendalam pada realitas yang ada sebagai tanda-tanda kebesaran Tuhan, berasaskan pada kesadaran kehadiran-Nya dalam segala macam ciptaan-Nya yang berada di manapun, baik di langit maupun di bumi. Tujuannya supaya manusia tidak menyia-nyaiakan ciptaan yang telah dibuat oleh Tuhan dan terhindar dari siksa neraka. ${ }^{47}$

Di samping itu, lanjut Musa, berpikir kenabian adalah langkah memberikan warning bagi manusia agar tidak melewati batas-batas kekuasaan Tuhan. Oleh sebab itu, manusia harus dibebaskan dari pengaruh hawa nafsunya, yang bisa berakibat matanya buta tidak melihat realitas kebenaran, telinganya tuli untuk mendengarkan kebenaran, dan hatinya tertutup dari kebenaran. Supaya terhindar dari sikap tersebut, dasar yang digunakan dalam berpikir kenabian adalah prinsip

${ }^{44}$ M. Amin Abdullah, Islamic Studies, 400-401.

45 Musa Asy'arie, Rekonstruksi Metodologi Berpikir Profetik: Perspektif Sunnah Nabi (Yogyakarta: LESFI, 2016), v.

${ }^{46}$ Musa Asy'arie, Rekonstruksi Metodologi Berpikir Profetik: Perspektif Sunnah Nabi, 6-7.

${ }^{47}$ Musa Asy'arie, Rekonstruksi Metodologi Berpikir Profetik: Perspektif Sunnah Nabi, 151. 
tauhid, bahwa hanya ada satu Tuhan, dan hanya ialah yang harus dipertuhankan oleh manusia. Manusia tidak menuhankan tuhan lainnya, ciptaan Tuhan, apalagi hanya sekedar ciptaannya sendiri. ${ }^{48}$

Pada dasarnya, berpikir kenabian adalah proses dan metodologi berpikir supaya manusia mampu memahami kebenaran dalam berbagai tahapannya secara utuh dan integratif. Ia tidak menolak dan menentang sains dan teknologi, akan tetapi menempatkannya pada posisi penemuan kebenaran yang bersifat relatif, berubah-ubah, dan tidak mutlak dan dimutlakkan. Sains dan teknologi diberikan dasar metafisis dan metateknis karena sains dan teknologi tidak pernah menjadikan realitas metafisis sebagai objek kajiannya. Masuknya metafisis dan metateknis dalam sains dan teknologi tidak untuk membatalkan kebenaran keduanya, namun sebagai tambahan perspektif untuk diperhatikan dalam merealisasikan dan mengaplikasikan sains dan teknologi di lapangan dengan memperhatikan kebenaran filsafat dan agama. ${ }^{49}$

Ada pula buku bunga rampai yang berkenaan dengan integrasi hadis dan keilmuan sosial bernama living hadis dari beberapa dosen jurusan Tafsir Hadis, yakni Metodologi Penelitian Living Qur'an dan Hadis. Lewat buku ini, beberapa dosen Tafsir Hadis UIN Sunan Kalijaga, seperti Sahiron Syamsuddin, M. Mansyur, Muhammad Chirzin, Muhammad Yusuf, Abdul Mustaqim, Suryadi, M. Alfatih Suryadilaga, dan Nurun Najwah memperkenalkan kajian baru dalam studi hadis yang dinamakan dengan living Qur'an dan hadis. Sahiron, editor buku tersebut, menjelaskan bahwa living hadis adalah hadis atau pemahamannya yang dipraktikkan dan dilembagakan oleh masyarakat kontemporer. Tentunya hal ini berkaitan erat dengan aspek aspek sosiologis dan antropologis. ${ }^{50}$

Menurut Suryadilaga, living hadis mempunyai kaitan yang erat dengan kebutuhan dan perkembangan masyarakat yang semakin kompleks dan diiringi dengan adanya keinginan untuk melaksanakan ajaran Islam yang sesuai dengan yang diajarkan oleh Nabi Muhammad saw., maka hadis pun menjadi suatu yang hidup di masyarakat. ${ }^{51}$ Lebih jauhnya, living hadis didasarkan pada tradisi yang hidup di masyarakat yang disandarkan kepada hadis. Adanya penyandaran pada hadis tersebut bisa saja dilakukan terbatas pada daerah tertentu saja dan atau bisa juga terjadi dalam wilayah yang lebih luas cakupan pelaksanaanya. Namun, meskipun cakupan pelaksanaannya luas, tetapi adanya lokalitas wajah masingmasing bentuk praktik di dalam masyarakat pun tidak dapat disangsikan eksistensinya. ${ }^{52}$ Ia kemudian membagi living hadis dalam tiga kategori, yaitu tradisi tulisan, lisan, dan praktik. ${ }^{53}$

${ }^{48}$ Musa Asy’arie, Rekonstruksi Metodologi Berpikir Profetik: Perspektif Sunnah Nabi, 151.

${ }^{49}$ Musa Asy'arie, Rekonstruksi Metodologi Berpikir Profetik: Perspektif Sunnah Nabi, 153.

${ }^{50}$ Sahiron Syamsuddin 'Kata Pengantar: Ranah-Ranah Penelitian dalam Studi al-Qur'an dan Hadis" dalam Metodologi Penelitian Living Qur'an dan Hadis, ed. Sahiron Syamsuddin (Yogyakarta: Teras, 2007), xvi.

${ }^{51}$ M. Alfatih Suryadilaga "Model-Model Living Hadis" dalam Metodologi Penelitian Living Qur'an dan Hadis, ed. Sahiron Syamsuddin (Yogyakarta: Teras, 2007), 106.

${ }^{52}$ M. Alfatih Suryadilaga "Model-Model Living Hadis" 113.

${ }^{53}$ M. Alfatih Suryadilaga "Model-Model Living Hadis" 114-130. 
Salah satu penerapan studi living hadis yang cukup bagus adalah tulisan Suryadilaga dengan judul Mafhūm al-Salawàt 'inda Majmü'àt Joged Salawàt Mataram: Dirāsat fĩ al-Hadith al-Hayy (Pemahaman shalawat menurut komunitas Joged Shalawat Mataram: Studi Living Hadis) yang dipublikasikan di jurnal Studia Islamika tahun 2014. Tulisan ini memfokuskan kajian pada fenomena kebaradaan komunitas Shalawat Joged Mataram di Yogyakarta. Dalam kajiannya, Suryadilaga menyimpukan beberapa poin, yakni pertama, Joged Shalawat Mataram (JSM) merupakan tradisi sosial-budaya-keagamaan, yang bisa diklasifikasikan sebagai tarian spiritual; kedua, JSM adalah tradisi living hadis, sebab ada beberapa hadis yang dijadikan sebagai prinsip landasan dalam melaksanakan kegiatannya; ketiga, ia merupakan syiar budaya agama; dan keempat, ia merupakan gerakan yang menyuarakan pendidikan karakter melalui seni islami. ${ }^{54}$

Implementasi interkoneksi perlu dijelaskan lebih banyak mengingat model inilah yang paling banyak disukai di UIN Sunan Kalijaga. Mayoritas kajian hadis integratif di UIN Sunan Kalijaga berada pada wilayah ini, karena para pemikir di kampus ini sudah merasa cukup terkait keilmuan klasik yang kemudian diberikan sentuhan ilmu-ilmu kontemporer. Dalam konteks ini, keilmuan hadis didekati dengan beragam keilmuan lainnya, baik ilmu alam, ilmu sosial, maupun ilmu humaniora. Hadis mempunyai posisi sebagai objek materialnya, dan beragam ilmu pengetahuan tersebut menjadi objek formalnya. Penggunaan ilmu-ilmu lainnya berguna sebagai penambah khazanah dalam ilmu hadis, yang apabila merujuk pada kategori Syamsul Anwar berkutat pada komplementasi, konfirmasi, kontribusi, dan komparasi; atau dengan simplifikasi dari penulis berupa afirmasi, reinterpretasi, dan rejektivikasi.

Salah satu karya yang berkenaan dengan interkoneksi hadis dengan ilmuilmu lainnya adalah Hadis Versus Sains: Memahami Hadis-Hadis Mushkil karya Nizar Ali. Karya ini mencoba menggali pemahaman hadis yang bisa dipakai sebagai pemahaman alternatif pada hadis yang bertentangan dengan sains dan logika. Beberapa contoh hadis yang bertentangan dengan sains seperti, hadis matahari bersujud pada malam hari; hadis demam merupakan serpihan dari api neraka; hadis jinten hitam adalah obat dari segala macam penyakit; hadis lalat yang sayapnya membawa penyakit sekaligus obatnya; hadis tentang air zamzam yang dapat diminum sesuai dengan tujuan peminumnya; hadis perkembangan embrio manusia, hadis struktur tubuh (usus) orang mukmin berbeda dengan orang kafir; dan hadis makan kurma agar tidak lapar.

Di samping itu, hadis yang bertentangan dengan logika, sebagaimana disebutkan Nizar Ali, meliputi hadis Nabi Musa yang menempeleng malaikat maut (Izrail); hadis Nabi Musa mandi telanjang di depan umum; hadis tidak masuk neraka orang yang mengucapkan kalimat tauhid; hadis tentang kepemimpinan suku Quraisy; hadis larangan melukis makhluk bernyawa; hadis mengenai siksa kubur; hadis bahwa Nabi menggilir semua isterinya dalam satu malam; hadis larangan perempuan menjadi pemimpin.

54 M. Al-Fatih Suryadilaga, "Mafhūm al-Șalawāt 'inda al-Majmū'at Joged Sholawat Mataram: Dirāsat fi al-Hadīth al-Hayy," Studia Islamica: Indonesian Journal for Islamic Studies, Vol. 1, No. 3 (2014): 535-578. 
Menurut penuturan Nizar, terkadang kandungan matan hadis terlihat aneh dan pelik untuk dipahami dari sisi nalar dan ilmu pengetahuan. Jenis hadis inilah yang disebut dengan hadis mushkil. Keberadaan hadis seperti ini memberikan kesan negatif pada unat Islam, sehingga muncul pemikiran yang meragukan, bahkan menolak hadis yang terbukti susah dicerna atau terkesan bertentangan dengan ilmu pengetahuan. ${ }^{55}$ Untuk itulah perlu diberikan penjelasan secara utuh, apakah hadis yang bertentangan dengan sains dan logika dipahami secara tesktual, ataukah dipahami secara kontekstual, atau bahkan manusia belum menjangkau pemahaman hadis yang dinilai tidak logis tersebut. ${ }^{56}$

Menyikapi permasalahan di atas, Nizar mencoba untuk memberikan analisis terhadap hadis-hadis yang dinilai kontradiksi dengan logika dan sains. Prosedur yang dilakukannya adalah, apabila hadis yang kontradiksi termaktub dalam dalam Shahih al-Bukhari dan Muslim, maka kritik sanad dan matan ditiadakan, yang kemudian langsung dilanjutkan dengan pemahaman hadis. Namun, apabila hadis yang bertentangan diriwayatkan selain dua imam hadis tersebut, maka dilakukan kritik sanad dan matan terlebih dahulu. Jika hadis dinilai berkualitas shahih atau hasan, maka bisa dilanjutkan dengan pemahaman hadis. ${ }^{57}$ Untuk menyelesaikan problematika pemahaman yang menerpa hadis-hadis tersebut, disuguhkan beberapa pendekatan yang relevan, berupa kebahasaan, ilmu alam, ilmu sosial, dan ilmu humaniora.

Ada pula buku Ilmu Ma'anil Hadith: Paradigma Interkoneksi yang ditulis oleh Abdul Mustaqim, salah seorang tenaga pengajar di jurusan Tafsir Hadis UIN Sunan Kalijaga. Ma'ān al-Hadith sendiri secara terminologis didefinisikan Mustaqim sebagai berikut:

"ilmu yang mengkaji tentang bagaimana memaknai dan memahami hadis Nabi saw. dengan mempertimbangkan struktur linguistik teks hadis, konteks munculnya hadis (asbābul wurūd), kedudukan Nabi saw. ketika menyampaikan hadis, dan bagaimana menghubungkan teks hadis pada masa lalu dengan konteks kekinian, sehinga diperoleh pemahaman yang relatif tepat, tanpa kehilangan relevansinya dengan konteks kekinian." 58

Untuk bisa sampai pada definisi yang menjadi karakter dan tujuan dalam ilmu Ma'ān al-Hadith, Mustaqim menggunakan beberapa perangkat ilmu sosialhumaniora sebagai pendekatannya dalam proses interkoneksi, yakni historis, sosiologi, dan antropologi, serta menggunakan pula analisis gender. Dengan adanya bantuan dari ilmu-ilmu lainnya tersebut, ilmu Ma'ān al-Hadith bisa menjadi keilmuan yang terinterkoneksi dengan ilmu-ilmu sosial-humaniora, yang diharapkan bisa memperoleh makna yang relatif lebih tepat, dinamis, akomodatif, dan apresiatif terhadap perkembangan masa. Beberapa hadis yang dikaji Mustaqim

${ }^{55}$ Nizar Ali, Hadis Versus Sains: Memahami Hadis-hadis Musykil (Yogyakarta: Teras, 2008), 1.

${ }^{56}$ Nizar Ali, Hadis Versus Sains: Memahami Hadis-hadis Musykil, 10.

${ }^{57}$ Nizar Ali, Hadis Versus Sains: Memahami Hadis-hadis Musykil, 11.

58 Abdul Mustaqim, Ilmu Ma'ânil Hadîts Paradigma Interkoneksi: Berbagai Teori dan Metode Memahami Hadis Nabi (Yogyakarta: Idea Press, 2008), 5. 
dengan pendekatan historis, sosiologi, dan antroplogi adalah, hadis tentang larangan perempuan pergi sendirian; hadis larangan melukis makhluk bernyawa; dan hadis larangan perempuan menjadi pemimpin. Sedangkan hadis-hadis yang didekati dengan analisis gender adalah hadis tentang perbedaan jumlah kambing aqiqah laki-laki dan perempuan; hadis larangan perempuan meminta cerai; dan hadis larangan perempuan pergi tanpa mahram.

Mustaqim mengulas bahwa pendekatan historis adalah suatu cara memahami hadis dengan cara mempertimbangkan kondisi historis-empiris pada saat hadis itu disampaikan Nabi. Dengan kata lain, pendekatan ini dilakukan dengan cara mengaitkan ide atau gagasan yang terdapat dalam hadis dengan determinasideterminasi sosial dan situasi historis kultural yang mengitarinya. Adapun pendekatan sosiologis merupakan pendekatan yang akan menyoroti dari sudut posisi manusia yang membawanya kepada perilaku itu. Hal ini dilakukan dengan memahami hadis dengan tingkah laku sosial yang ada pada masa Nabi. Sedangkan pendekatan antropologi memperhatikan terbentuknya pola-pola perilaku itu pada tatanan nilai yang dianut dalam kehidupan masyarakat manusia. Mustaqim menambahkan bahwa ketiga pendekatan tersebut, yakni historis, sosiologis, dan antropologis secara simplisistis dapat disebut sebagai asbāb al-wurūd 'ammah (sebab-sebab munculnya hadis secara makro). ${ }^{59}$

Karya tentang interkoneksi yang benar-benar baru dan berkontribusi besar dalam pengembangan akademik dilakukan Syamsul Anwar lewat karyanya Interkoneksi Studi Hadis dan Astronomi. Dalam konteks ini, ia melakukan kajian hadis dengan ilmu astronomi dan menemukan hal baru yang belum terpikirkan dalam studi hadis sebelumnya. Dalam menulis karyanya, ia menggunakan tiga sumber rujukan, yakni sumber-sumber hadis berupa kitab-kitab hadis dan juga kitab ilmu hadis; karya-karya sejarah yang ditulis oleh sejarawan Muslim; dan sumbersumber astronomi dengan mengambil buku-buku astronomi secara umum, situssitus internet yang membicarakan astronomi, dan juga software astrronomi. ${ }^{60}$

Dengan data-data tersebut dan dianalisis secara komprehensif, ia berhasil menghasilkan beberapa temuan penting. Pertama, Syamsul memberikan jawaban atas pertanyaan kapan hadis Kuraib tentang masalah matlak yang terkenal dalam studi ilmu falak muncul? Jawaban atas pertanyaan ini tidak mungkin diperoleh dari data hadis semata, akan tetapi harus dengan bantuan ilmu astronomi. Berdasarkan analisis sejarah dan astronomi, hadis Kuraib diperkirakan muncul pada tahun $35 \mathrm{H}$ saat menjelang terbunuhnya Khalifah 'Usman bin 'Affan. ${ }^{61}$

Kedua, dengan astronomi, Syamsul mengonfirmasi kebenaran kritik hadis yang menyebutkan bahwa hadis tentang idul fitri yang pernah jatuh pada hari jum'at adalah dhaif. Secara astronomis tidak ditemukan adanya data astronomis yang membenarkannya, oleh karenanya keterangan ini menguatkan justifikasi kelemahan hadis tersebut. Kemudian, untuk hadis yang menyatakan pernah terjadi

59 Abdul Mustaqim, Ilmu Ma'ânil Hadîts Paradigma Interkoneksi: Berbagai Teori dan Metode Memahami Hadis Nabi, 60-64.

60 Syamsul Anwar, Interkoneksi Studi Hadis dan Astronomi (Yogyakarta: Suara Muhammadiyah, 2011), 4-5.

${ }^{61}$ Syamsul Anwar, Interkoneksi Studi Hadis dan Astronomi, 73-115. 
hari raya di hari jum'at tanpa menyebutkan jenis hari rayanya yang dinyatakan shahih oleh para ulama hadis, setelah dilakukan kajian secara astronomis, diketahui bahwa memang pernah ada hari raya yang jatuh bersamaan dengan hari jum'at pada masa Nabi, dan itu adalah idul adha pada tahun $8 \mathrm{H}$ yang bertepatan dengan tanggal 3 Maret $630 \mathrm{M}$. Tent unya ini menguatkan keshahihan hadis tersebut. ${ }^{62}$

Ketiga, ilmu astronomi berhasil mendeteksi kesalahan dalam periwayatan hadis mengenai gerhana matahari di zaman Nabi dan wafatnya Ibrahim, putra Nabi Muhammad. Meskipun secara sanad suatu hadis berkualitas shahih misalnya, namun karena dikoreksi dan tidak sejalan dengan temuan astronomi, maka hadis itu bisa dikatakan dhaif dari segi matan. Temuan astronomi menyebutkan bahwa gerhana yang bertepatan dengan kematian Ibrahim terjadi pada hari Senin 27 Januari 632 M (29 Syawal $10 \mathrm{H})$. Astronomi juga mengonfirmasi kebenaran riwayat-riwayat yang mengatakan usia Ibrahim saat meninggal adalah 1 tahun 10 bulan. Namun, ia juga mengoreksi riwayat yang populer dalam berbagai literatur yang menyebutkan bahwa Ibrahim meninggal tanggal 10 Rabi'ul Awal tahun 10 H. ${ }^{63}$

\section{Hadis dalam Konsep Shajarah al-'Ilm}

\section{Shajarah al-'Ilm Sebagai Identitas UIN Maulana Malik Ibrahim Malang}

Dalam konteks UIN Maulana Malik Ibrahim (selanjutnya disebut Maliki), Shajarah al-'Ilm mempunyai peran penting dalam membentuk karakter keilmuan yang ada di kampus ini. Shajarah al-'Ilm dikreasi oleh Imam Suprayogo, yang pernah menjabat pimpinan tertinggi dalam beberapa tahapan transformasi kampus ini, yaitu periode Sekolah Tinggi Agama Islam Negeri (STAIN), periode Universitas Islam Indonesia-Sudan (UIIS), dan periode Universitas Islam Negeri (UIN) selama 16 tahun sejak 1997 hingga 2013. Ia lah tokoh yang berhasil melakukan "jumping" akademik dari STAIN langsung ke UIN, yang tidak pernah dicapai oleh kampus manapun di Indonesia sampai sekarang. ${ }^{64}$ Kedudukannya di UIN Maliki sangat penting, sehingga ia disebut sebagai Imam al-Jami' ${ }^{\prime} h^{65}$

Imam melihat bahwa sebenarnya Islam merupakan agama yang universal yang cakupannya sangat luas. Namun, dalam kehidupan sehari-hari, umat Islam hanya memahaminya dengan ritual ibadah sehari-hari. Ketika seseorang membicarakan Islam, maka hanya menyangkut tentang rukun Iman dan rukun Islam yang meliputi keharusan membaca dua kalimat syahadat, salat, zakat, puasa, dan haji semata. Fenomena aneh lainnya, saat yang dibicarakan adalah sejarah dan politik, maka hal-hal menyangkut tentang perang yang dibicarakan. Akibatnya Islam seolah-olah identik dengan perang. Padahal, Islam seharusnya mampu melahirkan kemakmuran, kedamaian, keadilan, dan peradaban unggul, akan tetapi

${ }^{62}$ Syamsul Anwar, Interkoneksi Studi Hadis dan Astronomi,117-138.

${ }^{63}$ Syamsul Anwar, Interkoneksi Studi Hadis dan Astronomi, 158-180.

${ }^{64}$ Muhammad In'am Esha, Institutional Transformation: Reformasi dan Modernisasi Pendidikan Tinggi Islam (Malang: UIN Malang Press, 2009), 119-130.

${ }^{65}$ Taufiqurrahman, Imam al-Jami'ah: Narasi Indah Perjalanan Hidup dan Pemikiran Prof. Dr. H. Imam Suprayogo (Malang: UIN Malang Press, 2010). 
ternyata masih belum berhasil diwujudkan oleh umat Islam sendiri. Salah satu upaya fundamental dan strategis yang ditempuh UIN Maliki adalah melakukan rekonstruksi paradigma keilmuan dengan meletakkan agama sebagai basis ilmu. Upaya tersebut dipandang fundamental dan strategis bahkan dalam kerangka pengembangan kampus ini ke depan. ${ }^{66}$

Secara lebih konkret, perbedaan pola kajian dikotomik di perguruan tinggi Islam dengan di UIN Maliki yang menggunakan paradigma integratif dapat dilihat dalam gambar berikut:

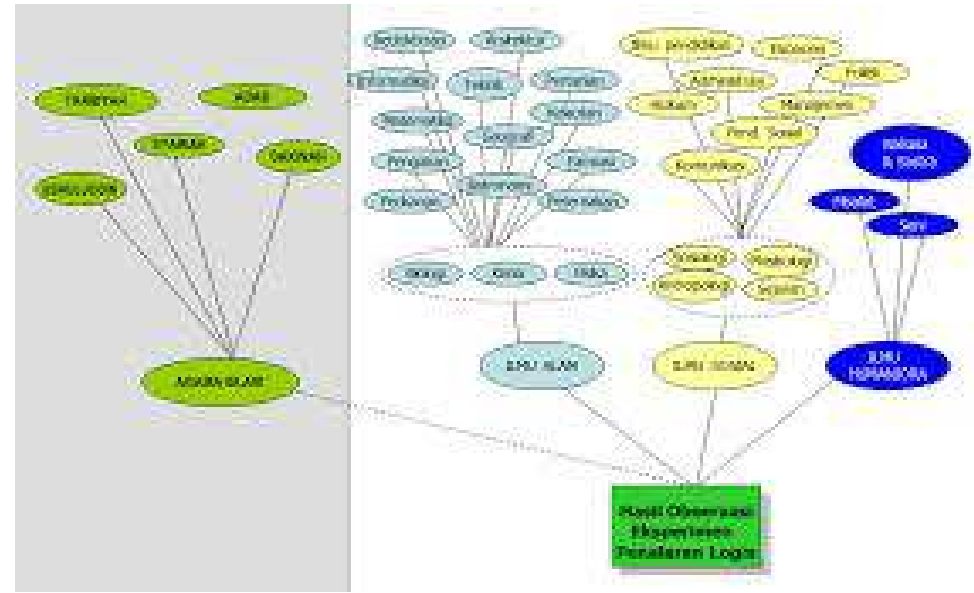

Gambar 3: Keilmuan Dikotomik

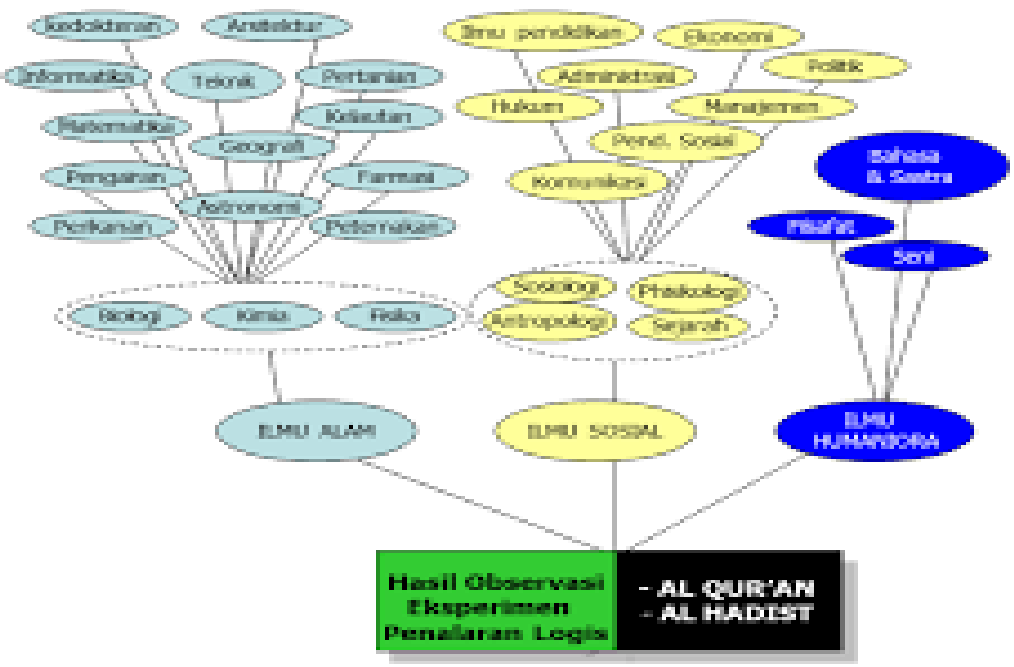

Gambar 4: Keilmuan integratif UIN Malang

Terlihat dari gambar 3, ilmu-ilmu agama Islam yang bersumber dari Alquran dan hadis berada terpisah dengan ilmu-ilmu umum yang didapatkan melalui

${ }^{66}$ Mohammad Muslih, "Tren Pengembangan Ilmu di Universitas Islam Negeri Maulana Malik Ibrahim Malang,” Teosofi: Jurnal Tasawuf dan Pemikiran Islam, Vol. 6, No. 1 (2016) 223. 
observasi, eksperimen, dan penalaran logis. Ilmu agama Islam pun diletakkan sejajar dengan ilmu-ilmu umum, sehingga menampakkan pola dikotomi keilmuan; ini adalah ilmu agama dan itu adalah ilmu umum. Oleh sebab itu, pemikiran perlu dirubah seperti gambar 4 yang mengilustrasikan bahwa observasi, eksperimen, dan penalaran logis (kawniyah) dan Alquran-hadis (qawliyah) secara bersama-sama menjadi sumber bagi ilmu-ilmu umum yang ada sekaligus. Dengan demikian, dengan mengaplikasikan model gambar kedua, tidak akan ada lagi pandangan dikotomi keilmuan, karena Alquran dan hadis sudah masuk di dalamnya menjadi sumbernya langsung. ${ }^{67}$

Berdasarkan keterangan di atas, konsep integrasi agama dan ilmu yang digunakan sebagai blue print pengembangan keilmuan di UIN Maliki sebenarnya merupakan upaya untuk menghilangkan dikotomi keilmuan Dengan demikian, pengetahuan keislaman yang dikembangkan oleh UIN Maliki adalah ilmu pengetahuan yang dibangun berdasarkan ajaran Islam yakni Alquran dan hadis, sekaligus pengetahuan yang sama dibangun berdasarkan hasil observasi, eksperimentasi, dan penalaran logis. Jika Alquran dan hadis diletakkan pada posisi sumber ilmu, maka tidak akan terjadi cara pandang ilmu yang dikotomik yang justru malah merendahkan posisi Kitab Suci. Sudah barang tentu sebagai konsekuensinya, Alquran yang bersifat universal masih diperlukan sumber pengetahuan lain yang bersifat teknis, yaitu ilmu pengetahuan yang diperoleh melalui observasi, eksperimen, dan penalaran logis. ${ }^{68}$

Shajarah al-'Ilm adalah metafora pengembangan keilmuan di UIN Maliki yang menginginkan agar civitas akademika menjadi pribadi yang bercirikan Ulü al$A l b \bar{a} b$ sesuai petunjuk Alquran. Karakter Ulü al-Albāb merupakan jargon yang diusung oleh UIN Maliki sesuai dengan QS. Āli 'Imrān (3): 191. Dalam ayat ini, Ulü al-Albāb disebutkan dengan "Orang yang senantiasa berzikir dalam setiap kondisi (berdiri, duduk, dan berbaring) dan selalu berpikir dalam penciptaan langit dan bumi." Secara mudahnya, bisa dikatakan bahwa Ulü al-Albāb merupakan pribadi yang mampu mengolaborasikan antara zikir, pikir, dan amal saleh.

Konsep metafora Shajarah al-'Ilm pada hakikatnya berpijak pada Alquran, sumber pertama keislaman. Berdasarkan perenungan pada Alquran, mempelajari kandungan maknanya, dan melihat realitas pendidikan Islam yang ada, Imam mencoba untuk merancang konsep yang hendak diaplikasikan di UIN Maliki berbentuk pohon yang mempunyai akar, dahan, ranting, daun, dan buah. ${ }^{69}$

67 M. Zainuddin, Paradigma Pendidikan Terpadu: Menyiapkan Generasi Ulul Albab (Malang: UIN Malang Press, 2010), 159-167.

68 Husniyatus Salamah Zainiyati, "Landasan Fondasional Intergasi Keilmuan di UIN Maulana Malik Ibrahim Malang dan UIN Sunan Ampel Surabaya," Islamica: Jurnal Studi Keislaman, Vol. 10, No. 1 (2015): 268.

69 Imam Suprayogo, Universitas Islam Unggul: Refleksi Pemikiran Pengembangan Kelembagaan dan Reformulasi Paradigma Keilmuan Islam (Malang: UIN Malang Press, 2009), 27. 


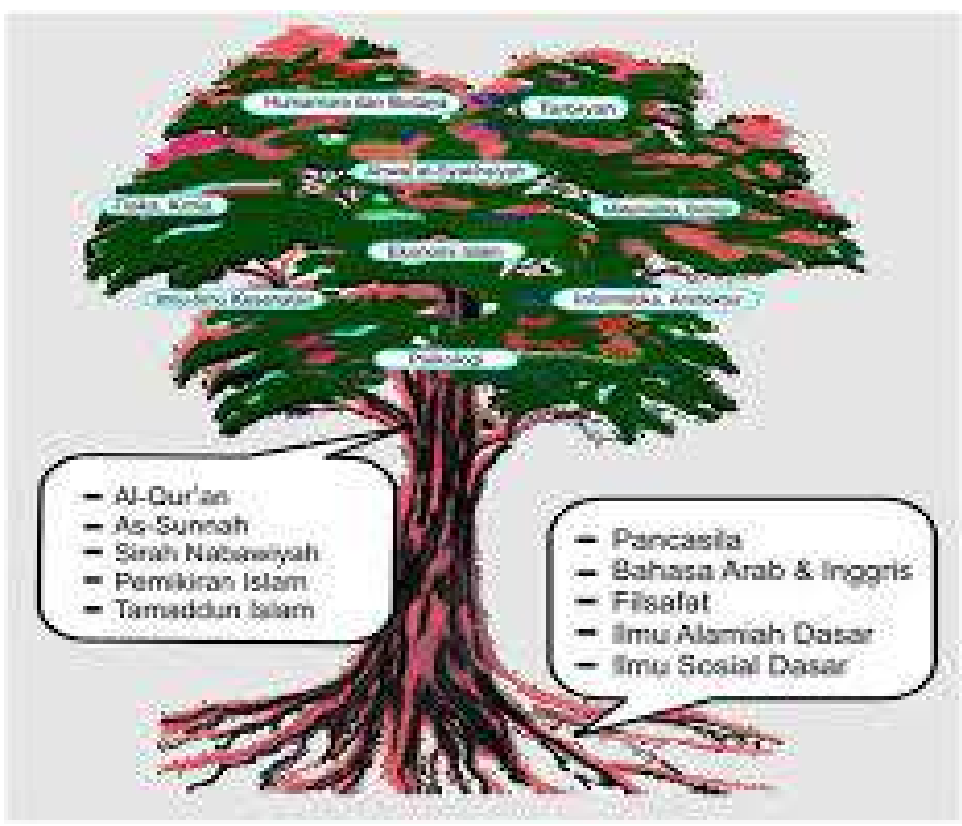

Gambar 8: Shajarah al-'Ilm

Pohon yang menjadi metafora pengembangan keilmuan di UIN Maliki diilustrasikan memiliki akar yang kokoh, dahan yang kokoh pula, ranting yang kuat, daun yang rindang, dan buah yang sehat dan segar. Masing-masing bagian mempunyai makna tersendiri. Akar melukiskan kemampuan berbahasa Arab dan Inggris, logika dan filsafat, ilmu-ilmu alam, dan ilmu-ilmu sosial. Sementara itu, batang menggambarkan ilmu-ilmu yang mempunyai relasi dan berasal dari Alquran dan hadis, yakni studi Alquran, studi hadis, pemikiran Islam, dan sirah nabawiyah. Adapun dahan dan ranting melukiskan disiplin ilmu modern yang dipilih oleh civitas akademika, seperti ilmu kedokteran, filsafat, psikologi, ekonomi, sosiologi, teknik, dan lain sebagainya. Bagian terakhir, buah dari pohon ilmu tersebut adalah ilmu, iman, amal saleh, dan akhlak yang mulia. Konsep pohon ilmu memberikan pemahaman bahwa mendalami ilmu yang bersumber dari Alquran dan hadis (akar dan batang) adalah wajib 'ain, sedangkan mendalami ilmu yang bersumber dari manusia (dahan dan ranting) mempunyai hukum wajib kifayah. ${ }^{70}$ Konsep hukum wajib 'ain dan wajib kifăyah ini diambil dari pemikiran Hujjah al-Islām, Imam alGhazāTi. Ilmu-ilmu ukhrawi dihukumi wajib 'ain dan ilmu-ilmu keduniaan dihukumi wajib kifayah.

Secara institusi, untuk mendukung konsep Shajarah al-'Ilm sekaligus mengatasi kelemahan mahasiswa di bidang agama, UIN Maliki membentuk Ma'had 'Ali (pesantren tinggi) Sunan Ampel sebagai tempat mahasiswa mengasah keilmuan dasar agama Islam, baik fikih, Alquran, hadis, maupun bahasa Arab, yang dibangun dan dimulai kegiatannya pada tahun 2000. Khusus untuk bahasa Arab sendiri, penggemblengan secara intens dilaksanakan oleh PKPBA (Program Khusus

${ }^{70}$ Tim Perumus, Tarbiyah Uli al-Albab: Dzikir, Fikr, dan Amal Shaleh: Konsep Pendidikan Universitas Islam Negeri Maulana Malik Ibrahim Malang (Malang: UIN Maulana Malik Ibrahim, 2012), 11-13. 
Pengembangan Bahasa Arab) yang sekarang berubah nama menjadi PPBA (Program Pengembangan Bahasa Arab). Ma'had atau pesantren, menurut Imam, merupakan instrumen penting universitas dan dianggap sebagai rukun universitas (arkān al-Jāmi 'ah) yang ketiga setelah dosen dan masjid. ${ }^{71}$ Ma'had ini diperuntukkan bagi mahasiswa baru pada tahun pertama masuk UIN Maliki, dan terintegrasi dengan sistem kurikulum universitas. Artinya, ketika mahasiswa tidak lulus Ta 'Tim al-Afkār al-Islämī dan Ta 'Tim al-Qur'ān di Ma'had, maka ia tidak bisa mengambil mata kuliah keislaman seperti Studi al-Qur'an dan al-Ḥadith, dan Studi Fiqih, juga tidak bisa mengikuti ujian komprehensif. ${ }^{72}$

Dalam pemikiran Imam, Alquran tidak hanya berisi informasi keagamaan semata, tetapi juga mengandung informasi yang berkenaan dengan alam semesta. Setelah memahami dan mengkaji Alquran secara seksama, ia menyimpulkan bahwa Alquran berisi informasi yang sangat luar biasa. Selain berbicara mengenai Tuhan, penciptaan manusia, makhluk ghaib seperti malaikat, jin dan setan, ternyata Alquran juga memberikan informasi tentang jagad raya (kosmos, al- 'alam), bumi atau tanah (al-ardh), matahari (al-syams), bulan (al-qamar), bintang (al-najm), air (al-mā'), gunung (al-jabal), petir (al-barq), laut (al-bahr), binatang (al-an‘ām, albahāim), tumbuh-tumbuhan (al-nabātāt). Di samping itu juga, Alquran berbicara mengenai keselamatan, baik dunia dan akhirat. ${ }^{73}$

Berpijak pada keterangan tersebut, menurut Imam, sebenarnya tidak sulit untuk mengintegrasikan antara agama dan sains. Melalui Alquran dan hadis, sebagai dua sumber Islam yang berisi beragam pengetahuan lah integrasi itu dilakukan. Keduanya menjadi titik tolak (starting point) untuk melakukan eksperimentasi, observasi, dan juga kontemplasi. Begitu pula, kajian-kajian ilmiah bisa membuka cakrawala pemikiran guna memahami Alquran dan hadis Nabi. ${ }^{74}$ Imam menyadari bahwa ada dua ayat Tuhan di bumi, yakni ayat qawliyah berupa Alquran dan hadis, dan juga ayat kawniyah berupa hamparan jagad raya yang dapat dikenali dengan observasi, eksperimentasi, dan penalaran logis. Keduanya samasama merupakan tanda-tanda Allah dan memiliki tujuan yang sama yaitu mengungkapkan realitas, kebenaran, dan eksistensi Allah meski berbeda dalam pendekatan dan metodologi. Oleh karena itu, tegas Imam, keduanya menyatu dan selaras dalam aras yang paling tinggi. ${ }^{75}$

Imam kurang sepakat dengan pembagian bidang keilmuan yang ada selama ini di perguruan tinggi, seperti Fakultas Ushuluddin, Fakultas Tarbiyah, Fakultas Syariah, Fakultas Adab, dan Fakultas Dakwah. Hal ini dikarenakan kategori seperti itu akan tetap melanggengkan adanya dikotomi keilmuan, dan melahirkan pemahaman Islam yang sempit dan terbatas. Oleh karenanya, perlu reformulasi keilmuan agar menghilangkan dikotomi itu. Bagi Imam, agar terjadi integrasi

${ }^{71}$ Imam Suprayogo, Universitas Islam Unggul, 194.

${ }^{72}$ Husniyatus Salamah Zainiyati, "Model Kurikulum Integratif Pesantren Mahasiswa dan UIN Maliki Malang," Ulumuna: Jurnal Studi Keislaman, Vol. 18, No. 1 (2014): 139-158.

${ }^{73}$ Imam Suprayogo, Universitas Islam Unggul, 25-26.

${ }^{74}$ Imam Suprayogo, Universitas Islam Unggul, 26.

${ }^{75}$ Imam Suprayogo, Universitas Islam Unggul, 15-16. 
dengan baik, sumber kajian (source of knowledge) harus bersumber dari ayat qawliyah berupa Alquran dan hadis, dan ayat kawniyah berupa hasil observasi, eksperimen, dan kekuatan akal atau rasio sekaligus. Inilah yang seharusnya diterapkan dalam perguruan tinggi Islam, dan membedakan dengan perguruan tinggi umum yang hanya memakai ayat kawniyah saja. ${ }^{76}$

Berdasarkan pemikiran di atas, menurut Imam, tatkala UIN/IAIN/STAIN membukan jurusan pendidikan yang kajiannya bersumber dari ayat qawliyah dan kawniyah, maka sudah sama seperti jurusan Tarbiyah. Begitu pula jurusan ilmu hukum yang berdasarkan ayat qawliyah dan kawniyah, maka sama kedudukannya seperti jurusan Syariah. Hal sama terjadi pada jurusan komunikasi dengan Dakwah, jurusan filsafat dengan Ushuluddin, dan jurusan sastra dengan Adab. Ketika sumber kajian dalam jurusan-jurusan tersebut sudah menyentuh ayat qawliyah dan kawniyah sekaligus, maka posisinya sudah dianggap sama. ${ }^{77}$ Konsep integratif ini tidak mempersoalkan letak fakultas, jurusan, dan prodi agama karena kajian agama sudah included dalam struktur keilmuan ini. Memang disadari oleh Imam bahwa dengan pola seperti ini, jurusan atau fakultas agama dikhawatirkan bisa mati, namun dengan pola seperti inilah kajian Islam menjadi lebih menarik dan mempunyai kawasan yang luas. ${ }^{78}$

\section{Hadis dalam Shajarah al-'Ilm}

Dalam konsep kajian integratif UIN Maliki, hadis Nabi menjadi sumber pengetahuan bersama hasil observasi, eksperimen, dan penalaran logis bagi ilmuilmu pengetahuan. Ilmu-ilmu alam, sosial, dan humaniora sebagai macam-macam ilmu pengetahuan menempatkan posisi hadis sebagai inspirasi pengembangan keilmuannya. Hadis adalah ajaran Islam yang penting, sehingga ia harus dipakai sebagai pijakan untuk menjelaskan ilmu-ilmu hasil observasi, eksperimentasi, dan penalaran logis. Hadis sebagai ayat qawliyah masih diperlukan dalam ilmu-ilmu hasil observasi, eksperimen, dan penalaran logis.

Ini berarti, hadis akan memberikan "warna" dalam keilmuan alam, sosial, dan humaniora yang telah ada selama ini. Ilmu pengetahuan yang selama ini bisa dikatakan "kering" dari sentuhan-sentuhan sabda Nabi sebagaimana dipraktikkan di universitas-universitas umum, akan diberikan sentuhan profetik yang tentunya mengubah jalannya pengetahuan. Paradigma antroposentris dalam pengetahuan umum dirubah menjadi teo-antroposentris, sebab memasukkan unsur ketuhanan berupa hadis Nabi ke dalam ilmu alam, sosial, dan humaniora. Model berpikir seperti ini mengingatkan penulis pada teori Ilmu Sosial Profetik (ISP) yang dikonstruksi oleh Kuntowijoyo. Teori ini didasarkan atas surat Ali 'Imrān ayat 110 dan menghasilkan konsep humanisasi, liberasi, dan transendensi. ${ }^{79}$

Hal inilah yang barangkali menjadi penyebab statemen yang biasa digaungkan oleh UIN Maliki dan biasa penulis dengar, yakni "integrasi agama dan

${ }^{76}$ Imam Suprayogo, Universitas Islam Unggul, 49.

${ }^{77}$ Imam Suprayogo, Universitas Islam Unggul, 170.

${ }^{78}$ Imam Suprayogo, Universitas Islam Unggul, 172.

79 Lihat, Kuntowijoyo, Islam Sebagai Ilmu: Epistemologi, Metodologi, dan Etika (Yogyakarta: Tiara Wacana, 2007). 
sains", karena diharapkan hadis Nabi (qawliyah) dapat melebur bersama ilmu-ilmu hasil observasi, eksperimen, dan penalaran logis berupa ilmu alam, ilmu sosial, dan humaniora (kawniyah). Terlihat dari gambar yang dibuat sebelumnya, UIN Maliki menginginkan penyatuan antara hadis dan ilmu-ilmu tersebut tanpa memisahkannya seperti yang sering terjadi di lingkungan perguruan tinggi Islam. Dalam konsep ini, tidak perlu mendirikan Fakultas Ushuluddin seperti yang diyakini Imam Suprayogo, tetapi cukup Fakultas Filsafat dengan memasukkan hadis sebagai inspirasi keilmuannya.

Konsep seperti ini juga yang membedakan belajar kedokteran misalnya, di Universitas Brawijaya (UB) dan UIN Maliki Malang. Belajar kedokteran di UB hanya mendasarkan pada hasil-hasil observasi dan eksperimen di laboratorium serta penalaran logika semata, sedangkan di UIN Maliki selain menggunakan hal tersebut juga ditambah dengan sabda-sabda Nabi Muhammad sebagai sumbernya. Inilah yang membedakan antara ilmu umum yang "asli" dengan yang sudah terintegrasi dengan hadis Nabi. Hadis yang merupakan wahyu Allah menjadi inspirasi dan sumber inspirasi penelitian-penelitian beragam keilmuan.

Secara sistem keilmuan, dalam konsep Shajarah al- IIm, hadis Nabi disebut dengan as-Sunnah berada di batang. Eksistensi hadis yang berada di batang berimplikasi bahwa ia tidak langsung dikaji dan diinterpretasikan, akan tetapi harus didahului oleh ilmu-ilmu dasar untuk memahaminya yang berada di akar. Ilmu-ilmu tersebut adalah Pancasila, Bahasa Arab dan Inggris, filsafat, Ilmu Alamiah Dasar (IAD), dan Ilmu Sosial Dasar (ISD). Adanya ilmu-ilmu di akar yang harus dikuasai sebelum beranjak pada batang yang salah satunya terhadap hadis memberikan pemahaman bahwa untuk bisa memahami hadis perlu ilmu-ilmu lain agar tidak mudah mencocok-cocokkan antara hadis dan sains. Ilmu alam, ilmu sosial, pancasila, termasuk juga filsafat yang dalam konsep UIN Sunan Kalijaga sebagai jembatan penghubung, serta bahasa Inggris dan Arab menjadi pijakan awal sebelum membangun integrasi antara agama dan sains.

Setelah selesai di batang yang salah satunya berisi hadis, maka berlanjut ke bagian dahan dan ranting berupa ilmu-ilmu yang dipilih oleh civitas akademika untuk didalami. Di UIN Maliki sendiri terdapat beberapa fakultas yang masuk kategori "umum", yakni Fakultas Humaniora, Fakultas Psikologi, Fakultas Sains dan Teknologi, Fakultas Ekonomi, dan Fakultas Kedokteran, selain Fakultas Tarbiyah dan Syariah yang masuk kategori fakultas agama. Dalam konteks ini, mahasiswa yang berada di naungan fakultas-fakultas tersebut mengembangkan keilmuan secara integratif berdasarkan hadis Nabi yang sudah dipelajari sebelumnya bersama dengan hasil eksperimen, observasi, dan penalaran logis.

Siklus keilmuan seperti disebutkan di atas sangat baik untuk membangun integrasi antara hadis dengan ilmu alam, sosial, dan humaniora sebagaimana yang dicanangkan oleh UIN Maliki. Tidak ada kebingungan konsep sebab aplikasinya tergambar jelas dalam konsep Shajarah al- 'Ilm. Pembaca pun sudah bisa mengerti bagaimana integrasi itu dimulai dan diakhiri. Pembelajaran dimulai dari akar, lalu ke batang, kemudian ke dahan dan ranting, yang kemudian mendapatkan buah dari itu semua. Setelah belajar ilmu-ilmu dasar, lalu berlanjut memahami hadis dan 
ilmu-ilmu di bagian batang, dan dilanjutkan dengan bidang keilmuan yang dipilih yang bisa mengantarkan ilmu-ilmu serba "profetik" yang menjadi ciri khas pendidikan di universitas Islam.

Integrasi antara hadis dan ilmu pengetahuan dalam konsep Shajarah al-' $\mathrm{Im}$ diperkuat dengan keberadaan Ma'had yang di dalamnya mengkaji berbagai kajian keislaman dasar, yang salah satunya adalah hadis Nabi. Mahasiswa diupayakan menguasi keilmuan dasar Islam, termasuk hadis, agar mampu memahami studi keislaman modern dalam perkuliahan, dan yang paling penting adalah membantu mereka dalam melakukan integrasi dalam studi yang dilakukan. Dalam menulis tugas akhir, mahasiswa diwajibkan mengutip dan mengintegrasikan ayat-ayat Alquran dan hadis Nabi ke dalam tulisannya, khususnya fakultas-fakultas yang berlabel umum. Begitu pula dosen yang mengajar pun harus menjelaskan materi perkuliahan dengan prinsip integrasi antara agama dan sains. Dalam pelatihan pedagogi dosen di UIN Maliki tahun 2015 yang pernah dijalani penulis, peserta "dipaksa" untuk melakukan integrasi dalam pembelajarannya, meskipun bagi dosen lulusan kampus umum yang boleh jadi minim pengetahuan agamannya. Dengan demikian, diharapkan dari sini, iklim akademik yang dibangun berprinsip integrasi antara agama dan ilmu.

Meskipun demikian, kajian hadis secara pure science bisa dikatakan belum dapat dilakukan UIN Maliki secara maksimal atau bisa jadi malah mati seperti disebutkan Imam, tidak sebagaimana di UIN Sunan Kalijaga, mengingat UIN Maliki belum mempunyai jurusan Ilmu Hadis. Jurusan yang mendekati Ilmu Hadis, yakni Ilmu Alquran dan Tafsir (IAT) memang ada, tapi baru dua angkatan di tahun ini (2018) dan itu pun berada di fakultas Syariah. Dalam konteks ini, jika ditelusuri secara historis, Imam Suprayogo memang terkesan kurang sepakat dengan adanya Fakultas Ushuluddin, fakultas yang secara nomenklatur menaungi jurusan Ilmu hadis, karena dua alasan, yakni karena Fakultas Ushuluddin merupakan fakultas yang tidak laku di pasaran dan karena banyak lahir tokoh nyeleneh dari Ushuluddin. Bahkan, secara tegas Imam menyatakan "tidak" untuk mendirikan fakultas Ushuluddin di UIN Maliki selama ia menjabat. ${ }^{80}$

Menurut informasi dari kalangan dosen Syariah, sebenarnya adanya jurusan Ilmu Alquran dan Tafsir di Fakultas Syariah pun adalah "titipan" dari Kementrian Agama sebagai embrio munculnya Fakultas Ushuluddin. Diharapkan sebelum melahirkan lulusan, jurusan IAT sudah harus dibuatkan "rumahnya" sendiri, yakni Fakultas Ushuluddin karena penempatannya di Fakultas Syariah tidak sesuai dengan nomenklatuir bidang keilmuan Kementrian Agama. Jika tidak berubah, gelarnya pun S.HI. (Syariah) dan bukan S. Ag. (Ushuluddin), gelar yang menimbulkan kebingungan secara keilmuan. Pancingan dari Kementrian Agama tersebut cukup dimaklumi karena dari sekian banyak UIN di Indonesia, hanya UIN Maliki Malang yang tidak mempunyai Fakultas Ushuluddin akibat prinsip yang dimiliki Imam Suprayogo, sang Imam al-Jami'ah.

Di samping itu, model integrasi seperti yang dipraktikkan di UIN Maliki tentunya akan lebih mengakomodir Alquran dibanding dengan hadis Nabi. Hal ini

80 Imam Suprayogo, "Usulan Pembukaan Fakultas Ushuluddin," https://www.uinmalang.ac.id (4 Septrember 2014), diakses 13 November 2018. 
dikarenakan Alquran lebih menarik daripada hadis. Alquran jelas secara lafal dan makna berasal dari Allah, sedangkan hadis hanya maknanya saja dari Allah, bahkan sebagian dari hadis berasal dari kemanusiaan Nabi sebagai orang Arab pada abad ke-7 Masehi. Kajian integratif pun akan lebih menarik dan mudah jika yang dipakai sebagai objek kajian adalah Alquran, karena itu adalah sumber pertama dan tidak terjebak pada wilayah otentisitas, tidak sebagaimana hadis Nabi. Dari beberapa karya yang disebutkan merupakan buku integrasi Islam dan sains, kebanyakan menyebutkan secara eksplisit dengan judul Alquran dan tidak menggunakan kata hadis di situ. ${ }^{81}$

\section{Implementasi Konsep Shajarah al-'Ilm ke dalam Karya-Karya Dosen}

Ada beberapa karya mengenai integrasi hadis dan ilmu pengetahuan yang dikaji dalam pembahasan ini. Salah satunya terdapat buku yang berjudul "Debu Semesta Rahmat: Interaksi Fisiokimia Debu dengan Air Liur Anjing" karya Himmatul Barroroh. Dalam konteks ini, Barroroh ingin menemukan alasan secara saintifik hadis Nabi yang menyebutkan najisnya air liur anjing dan debu menjadi syarat sucinya wadah yang dijilat anjing. Ia menelaah interaksi debu dengan air liur anjing dengan fisiko-kimia. Ia juga membandingkan antara interaksi air liur anjing dengan debu dan bahan pembersih yang ada di zaman sekarang. Barroroh mengaku tercengang dengan hasil penelitiaanya, yang ternyata membuktikan bahwa debu tanah tidak bisa tergantikan dengan bahan pembersih modern dewasa ini dalam kasus pembersihan air liur anjing. ${ }^{82}$

Hadis Nabi yang secara jelas berbicara mengenai najisnya air liur anjing sehingga harus disucikan dengan basuhan tujuh kali, dan salah satu basuhannya menggunakan debu, salah satunya adalah sebagai berikut:

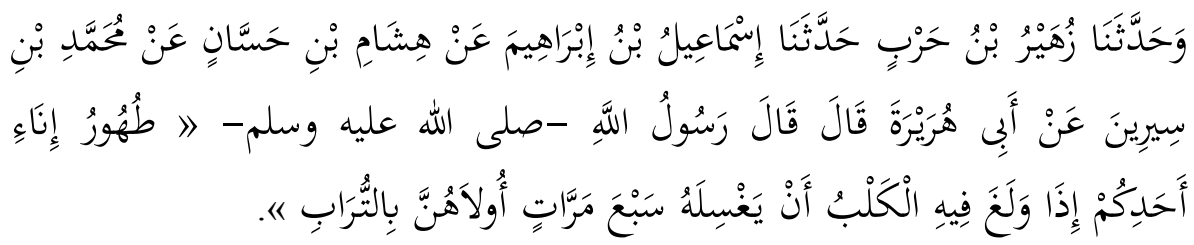

"Sucinya wadah seseorang di antara kalian adalah ketika ia dijilat anjing maka dibasuh sebanyak tujuh kali, dan salah satunya dicampur debu." ${ }^{93}$

${ }^{81}$ Lihat misalnya, Imron Rosidy, Fenomena Flora dan Fauna dalam al-Qur'an (Malang: UIN-Maliki Press, 2014); Misbahul Munir dan A. Djalaluddin, Ekonomi Qur'ani: Doktrin Reformasi Ekonomi dalam al-Qur'an (Malang: UIN-Maliki Press, 2014); A. Djalaluddin, Manajemen Qur'ani: Menerjemahkan Idarah Ilahiyah dalam Kehidupan Insaniyah (Malang: UIN-Maliki Press, 2014); Abdusysyakir, Matematika dalam al-Qur'an (Malang: UIN-Maliki Press, 2014); Kiptiyah, Embriologi dalam al-Qur'an: Kajian pada Proses Penciptaan Manusia (Malang: UIN-Maliki Press, 2014); Agus Mulyono dan Ahmad Abtokhi, Fisika \& al-Qur'an (Malang: UIN-Maliki Press, 2006).

${ }^{82}$ Himmatul Barroroh, Debu Semesta Rahmat: Interaksi Fisiokimia Debu dengan Air Liur Anjing (Malang: UIN-Malang Press, 2007), iv-v.

83 Abû al-Husain Muslim al-Hajjâj Muslim al-Qusyairî al-Naysâbûrî, al-Jâmi’ al-Shahîh, No. hadis 677, Vol. 1 (Beirut: Dâr al-Jayl, t.th.), 162. 
Baroroh menyatakan bahwa hasil interaksi air liur anjing dengan berbagai bahan surfaktan dan juga debu membuktikan bahwa debu sebagaimana tertera dalam hadis memang memberikan efek pembersihan yang lebih sesuai untuk alir liur anjing pada permukaan padatan. Padatan yang digunakannya dalam penelitian adalah gelas.$^{84}$ Ini berarti, sabda Nabi mengenai sucian air liur anjing dengan debu merupakan mukjizat ilmiah ( ${ }^{\prime} j \bar{j} \bar{z}$ ilm $\left.\bar{i}\right)$ dan tentunya akan menambah keimanan. Sesuai risetnya, Barroroh menyebutkan bahwa debu bersifat sangat menurunkan viskositas. Larutan debu dalam aquades (1\%) memberikam nilai viskositas 0,0096 poise, sedangkan larutan yang terdiri atas larutan air liur anjing (1:30) dan larutan debu $1 \%$ dengan perbandingan volume (1:1) memberikan nilai viskositas yang bahkan lebih rendah, yakni 0,009 poise, yang untuk air liur anjing murni akan menjadi 30 kalinya. ${ }^{85}$

Terdapat kajian integratif hadis dan etika bisnis yang ditulis oleh Muhammad Djakfar dengan titel "Etika Bisnis dalam Perspektif Islam". Ia fokus pada etika bisnis yang berlandaskan pada wahyu Allah berupa Alquran dan hadis Nabi. Ia mengulas bahwa perilaku menyimpang, seperti KKN (korupsi, kolusi, dan nepotisme) semakin menggurita di mayarakat. Tentu saja praktik tersebut bersetuhan dengan etika yang seharusnya dijunjung oleh setiap orang. Menyikapi hal tersebut, karya Djakfar menawarkan etika bisnis berdasarkan Alquran dan hadis untuk mengantisipasi atau meminimalisir perbuatan negatif itu. ${ }^{86}$

Ada banyak hadis yang dikutip Djakfar dalam karyanya. Salah satu di antaranya adalah hadis riwayat al-Tiirmidzi "Senyummu kepada saudaramu adalah sedekah bagimu" (tabassumuka liakhīka fahuwa shadaqah). Hadis ini menjadi pijakan dalam membangun salah satu prinisp etika bisnis dalam Islam, yaitu longgar dan bermurah hati. Menurut Djakfar, dalam sebuah transaksi, penjual harus bersikap ramah kepada pembeli, sebab itu menjadi kunci. Dengan cara ini, penjual akan mendapatkan berkah dan akan diminati oleh pembeli. Penjelasan seperti ini didasarkan atas hadis mengenai senyuman tersebut. ${ }^{87}$

Selain itu, ada pula hadis riwayat al-Tirmidzi lainnya yang dikutip sebagai landasan argumen normatif dalam membuat prinsip etika bisnis dalam Islam. Hadis tersebut adalah "Tinggalkan apa yang meragukanmu, karena sesungguhnya kejujuran (berkata benar) itu adalah membawa ketenangan dan kebohongan (berkata bohong) itu akan melahirkan kegelisahan.” Djakfar menyatakan bahwa salah satu prinsip etika bisnis dalam Islam adalah menjual barang yang mutunya berkualitas. Menyembunyikan mutu adalah sama seperti berbuat curang dan bohong, padahal bohong mengakibatkan ketidaktentraman sebagaimana isi kandungan hadis riwayat al-Tirmidzi tersebut. ${ }^{88}$

Selain dengan model-model di atas, ada pula karya yang berkenaan dengan living sunnah (atau hadis) yang ditulis oleh Umi Sumbulah, salah satu dosen

\footnotetext{
${ }^{84}$ Himmatul Barroroh, Debu Semesta Rahmat, 123.

${ }^{85}$ Himmatul Barroroh, Debu Semesta Rahmat, 122.

${ }^{86}$ Muhammad Djakfar, Etika Bisnis dalam Perspektif Islam (Malang: UIN-Malang Press, 2007), vii-ix.

${ }^{87}$ Muhammad Djakfar, Etika Bisnis dalam Perspektif Islam, 28.

${ }^{88}$ Muhammad Djakfar, Etika Bisnis dalam Perspektif Islam, 26.
} 
Fakultas Syariah, dengan judul Islam \& Ahlul Kitab Perspektif Hadis. Buku ini berkenaan dengan pemahaman organisasi masyarakat (ormas) NU, Muhammadiyah, dan HTI mengenai relasi Islam dan Ahl al-Kitab. Ia memfokuskan pada cabangnya yang ada di kota Malang. Dengan telaah living sunnah, Sumbulah melihat bagaimana masyarakat, yakni ormas NU, Muhammadiyah, dan HTI memahami hadis-hadis relasi Islam dan Ahl al-Kitab dan bagaimana mereka menerapkan dalam kehidupannya. Kajian dengan living sunnah berguna untuk menghindari justifikasi tertentu pada objek yang akan menghantarkan pada sikap truth claim.

Sumbulah menyimpulkan bahwa masing-masing ormas mempunyai perspektif yang berbeda dalam mendefinisikan siapa yang dimaksud Ahl al-Kitab. NU memahami Ahl al-Kitab sebagai komunitas Yahudi dan Nasrani, baik yang mengakui keesaan Allah maupun yang tidak. Muhammadiyah mempunyai definisi yang serupa dengan NU. Adapun HTI memaknai Ahl al-Kitab sebagai komunitas Yahudi dan Nasrani yang masih memiliki teologi yang tidak menyimpang atau bisa dikatakan masih murni. ${ }^{89}$

Selanjutnya, secara umum ketiga ormas tersebut tidak menolak untuk berinteraksi secara sosial dengan Ahl al-Kitab, dengan ekspresi yang beragam. Namun, dalam memahami hadis, ketiga ormas tersebut memiliki pola yang berbeda. NU menggunakan ilmu-ilmu keislaman murni yang dikombinasikan dengan ilmuilmu modern dan ada pula yang memakai pemahaman yang ditawarkan sarjana Muslim klasik. Sedangkan Muhammadiyah mempunyai pemahaman kontekstual dengan meminjam perangkat ilmu modern, seperti sosiologi-antropologi, dan historis. Adapun HTI masih terpaku dan tidak beranjak dari makna tekstual hadis. ${ }^{90}$

Kajian dengan pola yang sama, yakni menggali pemahaman suatu hadis di kalangan organisasi keagamaan yang sama, yakni NU, Muhammadiyah, dan HTI Malang juga dilakukan oleh Nasrullah, yang merupakan kolega Sumbulah di Fakultas Syariah dengan judul "Hadith-Hadith Anti Perempuan: Kajian Living Sunnah Perspektif Muhammadiyah, NU, dan HTI." Dalam konteks ini, Nasrullah menyoroti bagaimana ormas-ormas itu memahami hadis-hadis misoginis, yaitu hadis-hadis yang secara tekstual terkesan mendiskreditkan perempuan. Aneka ragam pemikiran pun ia dapatkan dari telaah terhadap tiga ormas itu dengan kacamata living sunnah. ${ }^{91}$

Sebenarnya, fokus living sunnah dua karya ini agak berbeda dengan living hadis yang digaungkan UIN Sunan Kalijaga. Jika dua karya ini lebih fokus pada pandangan ormas tertentu, akan tetapi living hadis di UIN Sunan Kalijaga lebih fokus pada praktik keagamaan suatu masyarakat, yang nantinya dilacak apakah mereka mendasarkan pada hadis atau tidak. Apabila mereka memang benar mendasarkan praktik keagamaannya pada hadis, maka bisa disebut sebagai fenomena living hadis. Oleh karenanya, living hadis di UIN Sunan Kalijaga terasa

${ }^{89}$ Umi Sumbulah, Islam \& Ahlul Kitab Perspektif Hadis (Malang: UIN-Maliki Press, 2012), 232-233.

${ }^{90}$ Umi Sumbulah, Islam \& Ahlul Kitab Perspektif Hadis, 233.

91 Nasrullah, Hadits-Hadits Anti Perempuan: Kajian Living Sunnah Perspektif Muhammadiyah, NU, dan HTI (Malang: UIN-Maliki Press, 2015). 
lebih "mentradisi" seperti kajian terhadap Shalawat Joged Mataram (SJM) tulisan M. Alfatih Suryadilaga yang telah diulas sebelumnya.

\section{Studi Komparatif Hadis dalam Spider Web dan Shajarah al-' $\mathrm{Ilm}$ \\ 1. Interaksi Keilmuan Hadis atau Hadis Sebagai Inspirasi?}

Interaksi keilmuan hadis dengan keilmuan lainnya, baik ilmu alam, sosial, dan humaniora menjadi ciri khas Spider Web. Kajian hadis dalam Spider Web terasa lebih mengedepankan objektivitas dalam studi Islam. Hadis bisa didekati dengan berbagai keilmuan sekaligus realitas yang dialami manusia, atau dengan kata lain, hadis Nabi mendapatkan sentuhan dari ilmu pengetahuan. Dengan kerangka integrasi, hadis dan ilmu pengetahuan dapat melebur menjadi sebuah diskursus keilmuan baru yang mempunyai kontribusi pada umat manusia. Sedangkan dengan kerangka interkoneksi, hadis bisa didekati dengan ilmu alam, sosial, dan humaniora, at au juga sebaliknya.

Dengan mekanisme integrasi dan interkoneksi UIN Sunan Kalijaga, hadis dapat "bergerak" ke arah manapun, selagi masih dalam kerangka integrasiinterkoneksi. Kajian Islam secara umum pun bisa lebih berkembang, sebab bisa terpetakan mana dimensi yang sakral dan profan. Sesuatu yang sakral hanyalah "sunnah" yang berada di bagian inti, sedangkan "hadith" yang berada pada ilmuilmu agama ( 'ulüm al-din) di lapisan ketiga bersifat profan. Karena sifat yang profan itulah, ia bisa menerima kritik, saran, perbaikan, dan sumbangan demi kebaikan ilmu yang bersangkutan. Dengan kata lain, harus dibedakan antara hadis dengan syarah atau pemahamannya. Mengkritik atau bahkan menyalahkan pemahaman hadis seseorang bukan berarti kemudian dimaknai sebagai kritik terhadap hadis itu sendiri.

Namun, hal berlainan terjadi di UIN Maliki Malang yang lebih condong pada hadis sebagai inspirasi. Meskipun Shajarah al-'Ilm berisi tingkatan pembelajaran yang menjadikan integrasi lebih terstuktur, akan tetapi lewat pola kajian gabungan agama dan ilmu mengesankan nuansa normatif, bahwa hadis merupakan ayat qawliyah yang harus dikembangkan bersama hasil observasi, eksperimentasi, dan penalaran logis, atau yang disebut ayat-ayat kawniyah. Ini berarti hadis menjadi inspirasi bagi pengembangan ilmu pengetahuan. Dalam konteks ini, subjektivitas sebagai seorang Muslim akan terpuaskan dalam konsep Shajarah al-'Ilm, sebab semua kajian eksperimen, observasi, dan penalaran yang dilakukan harus berlandaskan hadis sebagai salah satu sumbernya. Oleh sebab itu, dapat disebutkan bahwa konsep hadis integratif UIN Maliki sebenarnya lebih bersifat subjektif, dan lebih "menjaga" tradisi keislaman.

Menurut pengamatan penulis, iklim akademik di UIN Sunan Kalijaga dan UIN Maliki memang berlainan. Di UIN Sunan Kalijaga, iklim berpikir mengenai tema-tema keislaman begitu menggeliat tidak terbendung. Islam didekati dengan beragam keilmuan, utamanya ilmu-ilmu sosial-humaniora. Pemikiran keislaman, di tangan UIN Sunan Kalijaga, menjadi sangat berkembang pesat dengan dipertemukan dengan tradisi keilmuan lain, terlebih lagi di "gudangnya" pemikiran Islam, yakni Fakultas Ushuluddin. Objektivitas dalam studi Islam pun benar-benar dijaga di kampus ini, bahkan dalam beberapa kasus yang barangkali bagi Muslim 
"kanan" dianggap sebagai bentuk "pelecehan" terhadap ajaran Islam tetap memperoleh pujian secara akademik apabila pemikiran tersebut dibuat dengan teori dan mekanisme yang benar. ${ }^{92}$

Sementara itu, di UIN Maliki, hal yang paling menonjol adalah tradisi-tradisi keislaman dan kepesantrenan. Oleh karenanya, subjektivitas terlihat cukup menonjol dalam dunia akademik di kampus ini. Bahkan, sebagaimana dipaparkan sebelumnya, Imam Suprayogo tidak mau mendirikan fakultas Ushuluddin karena dianggap sebagai "gudang" pemikiran nyeleneh. UIN Maliki memang mempunyai pandangan spesial terhadap pesantren, karena dari itulah akan muncul ulama yang intelek dan intelek yang ulama. Aspek religiusitas keislaman pun sangat dijaga di kampus ini, mulai shalat zuhur secara berjamaah, ceramah setelah shalat dzuhur berjamaah, khatmil Alquran tiap bulan, dan acara shalawat sangat digalakkan di kampus ini. Hal yang sama tidak penulis dapatkan selama di UIN Sunan Kalijaga. Ini tidak berarti di UIN Sunan Kalijaga tidak mendukung relijiusitas keagamaan seseorang, hanya saja hal tersebut sudah tidak masuk di wilayah institusi. Berbeda dengan UIN Maliki yang menggenjot itu secara institusi.

\section{Integrasi Hadis yang Filosofis atau Integrasi Hadis yang Aplikatif?}

Spider Web merupakan karya seorang ahli filsafat yang concern menelaah wacana dalam Islamic studies, sehingga konsep yang terbangun di dalam Spider $W e b$ terasa sangat filosofis dan sophisticated. Amin Abdullah yang merupakan tenaga pengajar di Fakultas Ushuluddin dan Pemikiran Islam UIN Sunan Kalijaga adalah alumni dari fakultas tersebut. Kemudian, ia menyelesaikan doktoralnya di Department of Philosophy, Institute of Social Sciences, Middle East Technical University (METU) Ankara, Turki. Ia menyelesaikan doktoralnya pada tahun 1990 dengan disertasi tentang filsafat etis yang berjudul "The Idea of Universality of Ethical Norms in Ghazali and Kant." Tulisan-tulisan mengenai filsafat pun bertebaran dalam berbagai jurnal dan buku. Dengan demikian, kepakarannya dalam bidang filsafat tidak perlu diragukan lagi. Penulis sendiri mendapatkan inspirasi akademik-filosofis ketika menempuh studi pascasarjana dari Amin Abdullah, yang merubah jalan pemikiran penulis menjadi lebih benar-benar terstruktur dengan konsep being and time dan paradigm shift.

Namun di sisi lainnya, Imam Suprayogo, sang pengagas Shajarah al-'Ilm, merupakan dosen di Fakultas Ilmu Tarbiyah dan Keguruan UIN Maliki, yang juga adalah alumnus dari fakultas tersebut, yang dulunya masih bernama IAIN Sunan Ampel Malang. Ia boleh dikatakan merupakan ahli pendidikan yang banyak menulis dalam diskursus pengembangan keilmuan di perguruan tinggi, meskipun disertasinya sendiri di Universitas Airlangga (UNAIR) Surabaya berkenaan dengan sosial-politik dunia pesantren. ${ }^{93}$ Ia juga konsisten menulis artikel tiap harinya sampai sembilan tahun berjalan ini dan dipublikasikan di website UIN Maliki dan

\footnotetext{
92 Mengenai kritik dari Muslim kanan ini lihat misalnya, Adian Husaini, Hegemoni KristenBarat dalam Studi Islam di Perguruan Tinggi (Jakarta: Gema Insani, 2006).

${ }^{93}$ Lihat buku hasil disertasinya, Imam Suprayogo, Kyai dan Politik: Membaca Citra Politik Kyai (Malang: UIN-Malang Press, 2009).
} 
di website pribadinya, sehingga berkali-kali mendapatkan penghargaan atas prestasinya itu. Total sudah lebih dari 3000 artikel yang sudah dihasilkannya dengan menulis di tiap pagi hari. ${ }^{94}$ Dengan corak keilmuan pendidikan, Imam membuat konsep Shajarah al-'Ilm dan diterapkan di UIN Maliki.

Berdasarkan latar belakang pembuat konsep yang berbeda tersebut, dan akhirnya diaktualisasikan dalam dua konsep yang berlainan, maka hadis integratif juga berada dalam wilayah dan dimensi berbeda. Dalam Spider Web, integrasi hadis terasa sangat filosofis, dan memerlukan waktu yang cukup untuk bisa memahami dengan benar apa dan bagaimana hadis bisa berinteraksi dengan keilmuan lainnya dalam konsep tersebut. Awalnya harus dipahami hadis sebagai sentral, kemudian hadis dalam kerangka ilmu-ilmu keislaman klasik yang bersifat historis, yang diistilahkan oleh Amin dengan hadith. Setelah itu, hadith pun melakukan integrasiinterkoneksi dengan jenis keilmuan lainnya melalui pori-pori yang ada dalam konsep Spider Web. Filsafat sebagai jembatan penghubung antara peradaban teks dengan peradaban ilmu pengetahuan pun harus dipahami.

Alur berpikir semacam ini cukup menarik untuk dipahami oleh intelektual yang bergelut dalam dunia keislaman, sebab konsep itu mampu memetakan mana yang masuk kategori hadis secara normatif, hadis dalam kerangka 'Ulüm al-Dīn, hadis dalam kerangka al-Fikr al-Islāmī, dan hadis dalam kerangka Dirāsat Islāmiyah sesuai pembagian Amin. Pemahaman rumit seperti mendukung kajian hadis integratif-interkonektif yang lebih "menggelegar." Tulisan Syamsul Anwar mengenai interkoneksi hadis dan astronomi adalah salah satu contohnya. Dengan objek formal ilmu astronomi, ia berhasil membawa kajian baru dalam studi hadis yang sebelumnya hanya berputar-putar pada wilayah pemahaman yang tekstual dan kontekstual semata. Karyanya ini merupakan bentuk partisipasi sebagai dosen dalam pengembangan keilmuan di UIN Sunan Kalijaga berdasarkan filosofi pengembangan ilmu yang semula IAIN menjadi UIN. ${ }^{95}$

Sementara itu, hadis integratif dalam Shajarah al-'Ilm lebih bersifat aplikatif. Dalam memahami konsepnya, tidak membutuhkan waktu yang lama. Di mana posisi hadis dan kapan mengkajinya serta waktu yang tepat ketika mengintegrasikannya dapat tergambarkan secara jelas dalam konsep Shajarah al'Ilm. Ketika menerangkan integrasi di UIN Maliki kepada wali mahasiswa pun, Imam Suprayogo cukup menyodorkan metafora pohon ilmu, mereka sudah bisa memahami. Tahapan-tahapan aplikatif dalam belajar pun dapat tertata dengan rapi dan sistematis dalam konsep ini, berawal dari ilmu-ilmu di akar dahulu, kemudian batang, lalu dahan dan ranting. Yang paling akhir adalah buah yang didapatkan berupa ilmu, iman, amal saleh, dan akhlak yang mulia.

Cara berpikir seperti ini lebih menarik bagi kalangan yang bergelut dalam dunia sains yang kemudian ingin melakukan integrasi dengan hadis. Tidak akan terjadi kebingungan untuk menerapkan studinya, yakni dengan mengolaborasikan hadis sebagai ayat qawliyah dan ilmu alam, sosial, dan humaniora sebagai ayat kawniyah hasil eksperimentasi, observasi, dan penalaran logis. Konsep inilah

\footnotetext{
${ }^{94}$ Lihat, http://imamsuprayogo.com/ diakses 25 November 2018.

95 Syamsul Anwar, Interkoneksi Studi Hadis dan Astronomi (Yogyakarta: Suara Muhammadiyah, 2011), 1.
} 
pilihan logis bagi pengembangan ilmu umum yang berpijak pada hadis Nabi. Dalam pertemuan Dekan Fakultas Sains dan Teknologi PTAIN se-Indonesia, mereka lebih memilih konsep Shajarah al- IIm dibandingkan dengan Spider Web setelah mendengarkan presentasi dari masing-masing pengagas, yakni Imam Suprayogo dan M. Amin Abdullah. ${ }^{96}$

\section{Hadis dalam Islamic Studies atau Hadis dalam Ilmu Umum?}

Pada hakikatnya, Spider Web lebih sesuai diaplikasikan pada fakultas keagamaan yang berkolaborasi dengan ilmu alam, sosial, dan humaniora dalam membangun islamic studies. Begitu pula hadis Nabi pun akan lebih terasa "gregetnya" ketika berinteraksi dengan ilmu pengetahuan tersebut dalam kerangka berpikir Islamic Studies. Di UIN Sunan Kalijaga, diskursus keilmuan hadis dan perdebatannya sudah dikuasai selaras dengan usianya yang sudah tua, sehingga ia ingin melakukan integrasi-interkoneksi dengan perangkat ilmu lainnya. Jika ditengok secara lebih dekat, pengembangan hadis dan ilmu sosial-humaniora di UIN Sunan Kalijaga terasa sangat kuat. Dari beberapa contoh implementasi dosen, terlihat karya-karya hadis dan ilmu sosial-humaniora menghegemoni peta pemikiran hadis di UIN Sunan Kalijaga. Tren kajian hadis terbaru yang ada pun, yakni living hadis masih tidak melepaskan keilmuan sosial-humaniora. Namun, hal yang harus dipahami dari itu semua adalah bahwa pengembangan semua itu tidak keluar dari lingkaran Islamic Studies. Islamic Studies inilah yang menjadi daya pikat UIN Sunan Kalijaga secara akademis.

Menurut penuturan Muslih, karya dosen UIN Sunan Kalijaga begitu tinggi, baik secara kuantitas maupun kualitas, di bidang pengembangan paradigma keilmuan dan terutama di bidang Islamic Studies. Karya-karya itu memiliki pengaruh yang begitu besar pada dinamika pemikiran dan keilmuan, serta perkembangan masyarakat, baik yang mengapresiasi maupun yang menyalahpahami. Hal ini harus dimaknai sebagai bagian dari dinamika kreatif pemikiran dan keilmuan. Meskipun demikian, harus diakui bahwa karya dosen UIN Sunan Kalijaga terkait pengembangan keilmuan saintek dan sosial- humaniora, belum begitu terdengar pengaruhnya. Terkecuali buku-buku daras, belum banyak ditemukan buku karya dosen terkait bidang ini. ${ }^{97}$

Sementara itu, model pemikiran dalam Shajarah al-'Ilm lebih cocok dikembangkan pada fakultas ilmu umum guna membangun ilmu pengetahuan integratif hadis, yang mana mereka bisa membawa hadis sebagai sumber pengetahuan bersama ilmu-ilmu pengetahuan yang ada. Ia akan menampakkan "gregetnya" saat terjadi integrasi antara ilmu pengatahuan yang terinspirasi oleh ajaran-ajaran Nabi dalam hadisnya, misalnya saja ilmu-ilmu alam. Dalam konteks ini, ilmu-ilmu alam bisa mengonfirmasi kebenaran kandungan makna hadis, dan tent unya bisa meningkatkan kadar keimanan sebagai seorang Muslim. Hadis-hadis yang berkonten kealaman sendiri pun cukup banyak jumlahnya. Bahkan, al-Najjār,

${ }^{96}$ Disadur dari majalah GEMA.

${ }^{97}$ Mohammad Muslih, "Tren Pengembangan Ilmu di UIN Sunan Kalijaga Yogyakarta," Episteme: Jurnal Pengembangan Ilmu Keislaman, Vol. 12, No. 1 (2017): 132. 
salah seorang ahli geologi asal Mesir dalam bukunya "al-I'jāz al-Ilmī fí al-Sunnah al-Nabawiyah" mengkaji banyak sekali hadis-hadis tentang kealaman, mulai hadis tentang alam semesta, penciptaan manusia, keunggulan makanan tertentu, makanan yang diharamkan, obat-obatan, perilaku manusia, kematian dan kebangkitan, sampai tanda-tanda hari kiamat. ${ }^{98}$

Muslih menyatakan bahwa UIN Maliki besar-besaran dalam mencetak karya di bidang ilmu umum. Menurutnya, besarnya jumlah terbitan di bidang saintek dan beberapa di bidang ilmu sosial, membuat gema UIN Malang menjadi begitu besar, dan citranya dalam hal pengembangan ilmu umum berbasis agama (Alquran) menjadi semakin terbangun jelas di mata masyarakat. Namun, kondisi demikian tidak berbanding lurus dengan terbitan buku-buku di bidang ilmu keislaman yang terkait dengan pengembangan prodi-prodi agama. Buku-buku UIN Maliki tersebut dapat dikonsumsi oleh banyak kalangan, mulai dari santri, guru, mahasiswa, dan bahkan masyarakat umum..$^{99}$

Secara sekilas, sistem integrasi UIN Maliki terlihat menarik dan menjadikan keilmuan alam, sosial, dan humaniora "bersendikan" agama. Sistem pendidikan pun lebih tertata dengan urutan sebagaimana disebutkan dalam Shajarah al-'Ilm. Namun, permasalahan akan muncul dari fakultas yang benar-benar "agama" yang sudah "terlanjur" ada, seperti Fakultas Syariah. Konsep keilmuan integratif yang disebutkan oleh UIN Maliki terlihat kurang proporsional bagi keilmuan yang pure Islamic Studies, seperti Fakultas Syariah. Oleh sebab itu, tidak mengherankan bila Abbas Arfan, salah seorang dosen fakultas Syariah malah menyarankan agar iklim integrasi di UIN Maliki menggunakan intergrasi-interkoneksi khas UIN Sunan Kalijaga. Sungguh fenomena yang sangat unik. Ia berkata secara gamblang:

"Oleh sebab itu, penulis menyumbang saran pada kampus tercinta; UIN Maulana Malik Ibrahim Malang dalam menyongsong World Class University (WCU) ini hendaknya menggunakan pendekatan integrasiinterkoneksi dalam bidang akademik yang dimulai dengan menyusun ulang kurikulum dan silabi mata kuliah ilmu-ilmu agama Islam dan umum dengan etos dan nafas reintegrasi epistemologi keilmuan. Adapun prinsip-prinsip dasar yang harus dipertimbangkan dalam mewujudkan itu - sebagaimana dijelaskan M. Amin Abdullah - adalah kesatuan antara hadarät al-nash, hadarāt al-'Ilm, dan hadarāt al-falsafah."'100

\section{Apa yang Bisa Dilakukan?}

Dalam filsafat Hegel, terdapat istilah tesis, anti-tesis, dan sintesis. Tesis adalah pengetahuan awal yang muncul, yang kemudian dibantah oleh pengetahuan lain yang kontradiksi dengan pengetahuan awal. Pengetahuan kedua inilah yang

98 Zaghlûl Râghîb Muhammad al-Najjâr, al-I'jâz al-Ilmî fî̀ al-Sunnah al-Nabawiyah (alJâizah: Dâr Nahdhah Misr, 2012).

99 Mohammad Muslih, "Tren Pengembangan Ilmu di Universitas Islam Negeri Maulana Malik Ibrahim Malang," Teosofi: Jurnal Tasawuf dan Pemikiran Islam, Vol. 6, No. 1 (2016): 242.

100 Abbas Arfan, "Menyongsong World Class University: Dengan Pendekatan IntegrasiInterkoneksi atau Islamisasi Ilmu Pengetahuan?”, dalam Penguatan Kelembagaan Menuju Destinasi Utama: Pendidikan Islam Global Menyongsong World Class University, eds. Zainal Habib dan Ahmad Ghozi (Malang: UIN-Maliki Press, 2014), 34. 
dinamakan anti-tesis. Dengan kata lain, pengetahuan kedua mempunyai dimensi konfrontatif dengan pengetahuan pertama. Berbekal pada pengetahuan pertama sekaligus pengetahuan kedua, lalu muncul pengetahuan ketiga yang berusaha menggabungkan antara keduanya. Pengetahuan ketiga inilah yang disebut dengan sintesis.

Contoh yang bisa dikemukakan, misalnya mengenai diskurus ilmu teologi Islam terkait perbuatan manusia. Awalnya, muncul pengetahuan bahwa manusia tidak mempunyai daya apa-apa, mereka hanya mengikuti perbuatan yang telah dirancang oleh Allah. Manusia laksana wayang yang hanya mengikuti gerak tangan dalang. Dalam konsep perbuatan manusia, dalang tersebut adalah Allah. Pandangan seperti ini adalah pandanga kaum Jabariyah (fatalism), dan ini bisa dikatakan sebagai tesis. Banyak ayat Alquran yang dijadikan sandaran pandangan ini, salah sat unya adalah ayat "wa mā ramayta idz ramayta wa laākinna Allāha ramä" (Dan tidaklah kamu yang melempar tatkala kamu melempar, akan tetapi Allah lah yang melempar). ${ }^{101}$

Sebagai konfrontasinya, ada pemikiran bahwa manusia mempunyai kekuasaan penuh dalam menentukan perbuatannya, tanpa ada campur tangan Allah. Apa yang dilakukan manusia merupakan hasil perbuatannya sendiri. Oleh sebab itu, manusia wajib mempertanggungjawabkan apa yang dilakukannya kepada Allah. Inilah pemikiran yang dimiliki oleh kalangan Qadariyah (free wii), yang dapat dikategorikan sebagai anti-tesis. Banyak ayat pula yang dipakai sebagai sandaran pendapat kalangan Qadariyah, salah satunya adalah ayat Alquran "inna Allāha là yughayyiru mā biqawmin ḥattā yughayyiru mà bianfusihim" (Sesungguhnya Allah tidak merubah keadaan sebuah kaum sehingga mereka sendiri yang merubah keadaan yang ada pada dirinya). ${ }^{102}$

Berpijak pada tesis dan anti-tesis di atas, muncul pemikiran sintesisnya, yakni pemikiran Abū Hasan al-'Asyarì dengan teori kasb-nya, yang kemudian menjadi aliran Ahl al-Sunnah wa al-Jamā'ah. Dijelaskan bahwa manusia memang mempunyai daya, tapi semua itu atas kehendak dan kekuasaan Allah. Manusia hanya berusaha tetapi tetap Allah yeng menantukan keberhasilannya. Pemikiran seperti dinamakan dengan sintesis, sebab berhasil menggabungkan antara pemikiran Jabariyah dan Qadariyah.

Dalam ranah transformasi institusi, perubahan IAIN Sunan Kalijaga dan STAIN Malang menjadi UIN Sunan Kalijaga dan UIN Malang sebenarnya tidak menghilangkan tugas utama sebagai institusi penyelenggara bidang agama. Hanya saja, dengan perubahan menjadi universitas membuatnya mendapatkan tugas tambahan untuk mengembangkan program non-agama (umum). Keterangan ini sesuai dengan Surat Menteri Pendidikan Nasional yang ditujukan pada Menteri Agama tanggal 23 Januari 2004. ${ }^{103}$

\footnotetext{
${ }^{101}$ QS. al-Anfâl ayat 17.

${ }^{102}$ QS. al-Ra'd ayat 11.

103 M. Amin Abdullah, Islamic Studies di Perguruan Tinggi: Pendekatan IntegratifInterkonektif(Yogyakarta: Pustaka Pelajar, 2012), 367.
} 
Namun, dalam realitasnya terjadi perbedaan interpretasi dan aksi atas keterangan tersebut. UIN Sunan Kalijaga menambah fakultas ilmu umum, seperti Sains dan Teknologi dan fakultas Sosial dan Humaniora dengan tetap menjaga eksistensi kemajuan fakultas agama, seraya mengintegrasikan ilmu-ilmu dalam wujud kurikulum yang dirancang di fakulas agama dan fakultas umum. Sementara itu, UIN Maliki gencar menambah fakultas-fakultas umum, seperti Sains dan Teknologi, Ekonomi, Psikologi, dan yang terakhir Kedokteran. Tidak ada pengembangan fakultas ilmu agama yang berarti di UIN Maliki, padahal secara keilmuan masih banyak ilmu agama yang "kosong" di sini. Lewat pemikiran Imam Suprayogo, UIN Malang meyakini bahwa tidak perlu mendirikan jurusan atau fakultas agama, lebih baik mendirikan jurusan atau fakultas umum akan tetapi sumber pengetahuannya atau terinspirasi oleh Alquran dan hadis. ${ }^{104}$

Lantas, apa yang bisa kita lakukan? Menurut penulis, tidak perlu menjustifikasi mana yang unggul di antara kedua konsep hadis integratif tersebut. Masing-masing mempunyai kelemahan dan kelebihan sebagaimana dipaparkan sebelumnya. Sikap yang perlu dilakukan adalah membayangkan kedua konsep seperti tesis, anti-tesis, dan sintesis ala Hegel. Dengan demikian, akan tercipta gabungan pemikiran hadis integratif yang berguna untuk pengembangan studi hadis ke arah selanjutnya.

\section{SIMPULAN}

Spider Web dan Shajarah al-'Ilm merupakan dua konsep integrasi agama dan ilmu yang populer di Perguruan Tinggi Keagamaan Islam (PTKIN). Konsep pertama dimiliki UIN Sunan Kalijaga Yogyakarta, sedangkan konsep yang kedua dipunyai oleh UIN Maulana Malik Ibrahim Malang. Penulis menyimpukan bahwa dalam Spider Web, hadis berada dalam hadhärah al-nashsh yang berdialog dengan hadhārah al- 'ilm dan dijembatani oleh hadhārah falsafah. Di dalam konsep tersebut juga terdapat kata "sunnah" dalam arti normatifnya dan hadith dalam makna historisnya ( 'Ulüm al-Dīn), yang kemudian berinteraksi dalam al-Fikr al-Islämīi dan Dirāsat Islämiyah di kluster selanjutnya. Sementara dalam Shajarah al-' $\mathrm{Ilm}$, hadis Nabi menjadi sumber pengetahuan bersama ilmu-ilmu hasil observasi, eksperimentasi, dan penalaran logis. Dalam metafora konsep tersebut, posisi hadis berada di batang dan dilakukan pembelajaran secara bertahap dan tertata rapi. Kajian dilakukan mulai akar dahulu, kemudian batang, lalu dahan dan ranting, dan diakhiri oleh buah ilmu, iman, amal saleh, dan akhlak yang mulia.

Lebih lanjut, penulis juga menemukan beberapa perbedaan antara kajian hadis integratif dalam kedua konsep tersebut, yakni pertama, interaksi keilmuan hadis yang lebih bebas dalam Spider Web, dan munculnya hadis sebagai inspirasi yang tent unya memberi warna baru bagi ilmu pengetahuan dalam Shajarah al-'Ilm; kedua, integrasi hadis yang filosofis dan disukai pegiat studi Islam dalam Spider $W e b$, dan integrasi hadis yang aplikatif dan lebih disukai oleh saintis dalam

104 Meskipun sekarang sudah banyak civitas akademika yang menginginkan untuk mendirikan jurusan dan fakultas agama. Ini terlihat dari rencana pengembangan UIN Maliki yang direncanakan oleh Mudjia Raharjo, Rektor UIN Maliki sebelumnya, yang disampaikan dalam tiap pertemuan dosen-karyawan UIN Maliki. Namun, sampai sekarang, realisasinya belum nampak. 
Shajarah al-'Ilm; dan ketiga, hadis dalam Islamic Studies lebih berkembang dalam Spider $W e b$, dan hadis dalam ilmu umum lebih bisa berkembang dalam Shajarah al'Ilm.

\section{DAFTAR PUSTAKA}

Abdullah, M. Amin. Studi Agama, Normativitas atau Historisitas? Yogyakarta: Pustaka Pelajar, 2001.

Abdullah, M. Amin. "New Horizons of Islamic Studies Through Socio-Cultural Hermeneutics." al-Jāmi'ah: Journal of Islamic Studies, Vol. 41, No. 1 (2003): $1-24$.

Abdullah, M. Amin dkk., Kerangka Dasar Keilmuan dan Pengembangan Kurikulum Universitas Islam Negeri (UIN) Sunan Kalijaga Yogyakarta. Yogyakarta: Pokja Akademik UIN Sunan Kalijaga, 2006.

Abdullah, M. Amin. Islamic Studies di Perguruan Tinggi: Pendekatan IntegratifInterkonektif. Yogyakarta: Pustaka Pelajar, 2012.

Abdullah, M. Amin. "Religion, Science and Culture; An Integrated, Interconnected Paradigm of Science." al-Jāmi'ah: Journal of Islamic Studies, Vol. 52, No. 1 (2014): 175-203.

Abdullah, M. Amin, "Mempertautkan Ulum al-Diin, al-Fikr al-Islamiy dan Dirasat Islamiyyah: Sumbangan Keilmuan Islam untuk Peradaban Global" dalam https://aminabd.wordpress.com (10 Juni 2010), diakses 11 Nopember 2018.

Abdusysyakir. Matematika dalam al-Qur'an. Malang: UIN-Maliki Press, 2014.

Abu Bakar, Sayyid Shalih. Menyingkap Hadith-Hadith Palsu, terj. Muhamad Wakid. Solo: Mutiara Solo, t.th.

Afwadzi, Benny. "Membangun Integrasi Ilmu-Ilmu Sosial dan Hadis Nabi." Jurnal Living Hadis, Vol. 1, No. 1 (2016): 101-127.

Afwadzi, Benny. "Memahami Eksistensi Pendekatan Ilmu-Ilmu Alam dan Pemahaman Hadis Nabi." dalam Membangun Kembali Peradaban Islam Prestisius. Malang: UIN Maliki Press, 2016: 69-109.

Afwadzi, Benny. "Integrasi Ilmu-Ilmu Alam dan Ilmu-Ilmu Sosial dengan Pemahaman Hadis Nabi: Telaah atas Konsepsi, Aplikasi, dan Implikasi." Jurnal Theologia, Vol. 28, No. 2 (2017): 351-390.

Ali, Nizar. Hadis Versus Sains: Memahami Hadis-Hadis Mushkil. Yogyakarta: Teras, 2008

Aminuddin, Luthfi Hadi. "Integrasi Ilmu dan Agama: Studi atas Paradigma Integratif-Interkonektif UIN Sunan Kalijaga Yogyakarta." Kodifikasia: Jurnal Penelitian Keagamaan dan Sosial Budaya, Vol. 4, No. 1 (2010): 181214.

Anshori dan Zainal Abidin. "Format Baru Modern Hubungan Sains dan Islam: Studi Integrasi Keilmuan atas UIN Yogyakarta, dan Tiga Universitas Islam Swasta Sebagai Upaya Membangun Islam Seutuhnya Tahun 2007-2013, Profetika: Jurnal Studi Islam, Vol. 15, No. 1 (2014): 90-108. 
Anshori. "Integrasi Keilmuan atas UIN Jakarta, UIN Yogyakarta, dan UIN Malang", Disertasi. Yogyakarta: Pascasarjana UIN Sunan Kalijaga Yogyakarta, 2014.

Anwar, Syamsul. Interkoneksi Studi Hadis dan Astronomi. Yogyakarta: Suara Muhammadiyah, 2011.

Arfan, Abbas. "Menyongsong World Class University: Dengan Pendekatan Integrasi-Interkoneksi atau Islamisasi Ilmu Pengetahuan?", dalam Penguatan Kelembagaan Menuju Destinasi Utama: Pendidikan Islam Global Menyongsong World Class University, eds. Zainal Habib dan Ahmad Ghozi. Malang: UIN-Maliki Press, 2014: 17-37.

Asy'arie,Musa. Rekonstruksi Metodologi Berpikir Profetik: Perspektif Sunnah Nabi. Yogyakarta: LESFI, 2016.

Barroroh, Himmatul. Debu Semesta Rahmat: Interaksi Fisiokimia Debu dengan Air Liur Anjing. Malang: UIN-Malang Press, 2007.

Darda, Abu. "Integrasi Ilmu dan Agama: Perkembangan Konseptual di Indonesia." Jurnal At-Ta'dib, Vol. 10, No. 1 (2014): 33-46.

Djakfar, Muhammad. Etika Bisnis dalam Perspektif Islam. Malang: UIN-Malang Press, 2007.

Djalaluddin, A. Manajemen Qur'ani: Menerjemahkan Idarah Ilahiyah dalam Kehidupan Insaniyah. Malang: UIN-Maliki Press, 2014.

Esha, Muhammad In'am. Institutional Transformation: Reformasi dan Modernisasi Pendidikan Tinggi Islam. Malang: UIN Malang Press, 2009.

Al-Ghazāli, Abū Hạmid. al-Mustashfā min 'Ilm al-Ushūl. Beirut: Dār Kutub Ilmiyah, 2010.

Hakim, Lukman. "Quo Vadis Pengembangan Keilmuan UIN: Sekularisasi atau Qur'anisasi Ilmu Pengetahuan." Substantia: Jurnal Ilmu-Ilmu Ushuluddin, Vol. 16, No. 1 (2014): 35-48.

Husaini, Adian. Hegemoni Kristen-Barat dalam Studi Islam di Perguruan Tinggi. Jakarta: Gema Insani, 2006.

Ikhwan, Afiful. "Perguruan Tinggi Islam dan Integrasi Keilmuan Islam." At-Tajdid: Jurnal Ilmu Tarbiyah, Vol. 5, No. 2 (2016): 159-187.

Khathīb (al), Muhammad Ajjaj. Ushūil al-Hadith Ulümuhū wa Mushtholāhuhū. Beirut: Dār al-Fikr, 2011.

Kiptiyah. Embriologi dalam al-Qur'an: Kajian pada Proses Penciptaan Manusia. Malang: UIN-Maliki Press, 2014.

Kuntowijoyo. Islam Sebagai Ilmu: Epistemologi, Metodologi, dan Etika. Yogyakarta: Tiara Wacana, 2007.

Mulyono, Agus dan Ahmad Abtokhi. Fisika \& al-Qur'an. Malang: UIN-Maliki Press, 2006.

Munir, Misbahul dan A. Djalaluddin. Ekonomi Qur'ani: Doktrin Reformasi Ekonomi dalam al-Qur'an. Malang: UIN-Maliki Press, 2014.

Muslih, Mohammad. "Integrasi Keilmuan: Ide Mutakhir Filsafat Ilmu." Kalimah: Jurnal Studi Agama dan Pemikiran Islam, Vol. 14, No. 2 (2016): 245-272. 
Muslih, Mohammad. "Tren Pengembangan Ilmu di Universitas Islam Negeri Maulana Malik Ibrahim Malang." Teosofi: Jurnal Tasawuf dan Pemikiran Islam, Vol. 6, No. 1 (2016): 220-247.

Muslih, Mohammad. "Tren Pengembangan Ilmu di UIN Sunan Kalijaga Yogyakarta." Episteme: Jurnal Pengembangan Ilmu Keislaman, Vol. 12, No. 1 (2017): 103-139.

Mustaqim, Abdul. Ilmu Ma'ānil Hadith Paradigma Interkoneksi: Berbagai Teori dan Metode Memahami Hadis Nabi. Yogyakarta: Idea Press, 2008.

Najjār (al), Zaghlūl Rāghīb Muḥammad. al-I'jāz al-Ilmī fí al-Sunnah al-Nabawiyah. al-Jaizah: Dār Nahdhah Misr, 2012.

Nasrullah. Hadith-Hadith Anti Perempuan: Kajian Living Sunnah Perspektif Muhammadiyah, NU, dan HTI. Malang: UIN-Maliki Press, 2015.

Naysābūrì (al),Abū al-Ḥusain Muslim b. al-Hajjāj b. Muslim al-Qusyairì. al-Jāmi' al-Shahịh. Beirut: Dār al-Jayl, t.th.

Raya, Moch. Khafidz Fuad. "Model Pengembangan Keilmuan UIN Malang dan UIN Jogjakarta.” Falasifa: Jurnal Ilmu Keislaman, Vol. 8, No. 1 (2017): 6582.

Rifa'i, Nurlena dkk,. "Integrasi Keilmuan dalam Pengembangan Kurikulum di UIN se-Indonesia: Evaluasi Penerapan Integrasi Keilmuan UIN dan Kurikulum dan Proses Pembelajaran." Tarbiya: Journal of Education in Muslim Society, Vol. 1, No. 1 (2014): 13-33.

Riyanto, Waryani Fajar. Integrasi Interkoneksi Keilmuan Biografi Intelektual M. Amin Abdullah (1953....): Person, Knowledge, and Institution. Yogyakarta: Suka Press, 2013.

Riyanto, Waryani Fajar, Mazhab Sunan Kalijaga: Setengah Abad Genealogi Epistemologi Studi Hukum Islam Integratif di Fakultas Syari'ah dan Hukum UIN Sunan Kalijaga Yogyakarta (1963-2013 M/1383-1433 H). Yogyakarta: Fakultas Syari'ah dan Hukum UIN Sunan Kalijaga Yogyakarta dengan Kurnia Kalam Semesta, 2014.

Rosadisastra, Andi. "Integrasi Ilmu Sosial dan Teks Agama dalam Perspektif Tafsir al-Qur'an.” Mutawatir: Jurnal Keilmuan Tafsir Hadis, Vol. 4, No. 1 (2014): 87-116.

Rosidy, Imron. Fenomena Flora dan Fauna dalam al-Qur'an. Malang: UIN-Maliki Press, 2014.

Syamsuddin, Sahiron. "Kata Pengantar: Ranah-Ranah Penelitian dalam Studi alQur'an dan Hadis" dalam Metodologi Penelitian Living Qur'an dan Hadis ed. Sahiron Syamsuddin. Yogyakarta: Teras, 2007: xi-xvi.

Sumbulah,Umi. Islam \& Ahlul Kitab Perspektif Hadis. Malang: UIN-Maliki Press, 2012.

Suprayogo,Imam. "Rekonstruksi Kajian Keislaman (Sebuah Tawaran Ontologis dan Epistemologis)", dalam Horizon Baru Pengenbangan Pendidikan Islam: Upaya Merespon Dinamika Masyarakat Global, eds. M. Zainuddin dan Muhammad In'am Esha. Malang: UIN Press, 2004: 11-31 
Suprayogo, Imam dan Rasmianto. Perubahan Pendidikan Tinggi Islam: Refleksi

Perubahan IAIN/STAIN menjadi UIN. Malang, UIN Malang Press, 2008.

Suprayogo, Imam. Universitas Islam Unggul: Refleksi Pemikiran Pengembangan Kelembagaan dan Reformulasi Paradigma Keilmuan Islam. Malang: UIN Malang Press, 2009.

Suprayogo, Imam, Kyai dan Politik: Membaca Citra Politik Kyai. Malang: UINMalang Press, 2009.

Suprayogo, Imam. "Usulan Pembukaan Fakultas Ushuluddin", https:/www.uinmalang.ac.id (4 Septrember 2014), diakses 13 November 2018.

Suryadi. "Prospek Studi Hadis di Indonesia: Telaah atas Kajian di UIN, IAIN, dan STAIN." Jurnal Studi Ilmu-Ilmu al-Qur'an dan Hadis, Vol. 16, No. 1 (2014): $1-16$.

Suryadilaga,. M. Alfatih. "Model-Model Living Hadis" dalam Metodologi Penelitian Living Qur'an dan Hadis, ed. Sahiron Syamsuddin. Yogyakarta: Teras, 2007: 105-130.

Suryadilaga,. M. Alfatih. "Mafhūm al-Șalawāt 'inda al-Majmū'at Joged Sholawat Mataram: Dirāsat fi al-Hadīth al-Hayy." Studia Islamica: Indonesian Journal for Islamic Studies, Vol. 1, No. 3 (2014): 535-578.

Suryadilaga,. M. Alfatih. "Ragam Studi Hadis di Indonesia dan Karakteristiknya: Studi atas Kurikulum IAIN Bukit Tinggi, IAIN Batu Sangkar, UIN Sunan Kalijaga, dan IAIN Jember." Journal of al-Qur'ān dan Hadith Studies, Vol. 4, No. 2 (2015): 215-247.

Taufiqurrahman. Imam al-Jami'ah: Narasi Indah Perjalanan Hidup dan Pemikiran Prof. Dr. H. Imam Suprayogo. Malang: UIN Malang Press, 2010.

Tim Perumus. Tarbiyah Uli al-Albab: Dzikir, Fikr, dan Amal Shaleh: Konsep Pendidikan Universitas Islam Negeri Maulana Malik Ibrahim Malang. Malang: UIN Maulana Malik Ibrahim, 2012.

Yunus, Moh. "Integrasi Agama dan Sains: Merespon Kelesuan Tradisi Ilmiah di PTAI." Insania: Jurnal Pemikiran Alternatif Kependidikan, Vol. 19, No. 2 (Juli-Sesember 2014): 284-313.

Zainiyati, Husniyatus Salamah. "Model Kurikulum Integratif Pesantren Mahasiswa dan UIN Maliki Malang." Ulumuna: Jurnal Studi Keislaman, Vol. 18, No. 1 (2014): 139-158.

Zainiyati, Husniyatus Salamah. "Landasan Fondasional Intergasi Keilmuan di UIN Maulana Malik Ibrahim Malang dan UIN Sunan Ampel Surabaya.” Islamica: Jurnal Studi Keislaman, Vol. 10, No. 1 (2015): 248-276.

Zainuddin, M. Paradigma Pendidikan Terpadu: Menyiapkan Generasi Ulul Albab. Malang: UIN Malang Press, 2010.

http://iat.uin-suka.ac.id/ diakses tanggal 3 Oktober 2017.

http://ilmuhadis.uin-suka.ac.id/ diakses tanggal 3 Oktober 2017.

http://pmb.uin-malang.ac.id/ diakses tanggal 3 Oktober 2017.

http://uin-suka.ac.id/ diakses tanggal 3 Oktober 2017.

https://kemenag.go.id diakses 30 September 2017.

http://uin-suka.ac.id/id/organisasi/universitas, diakses 11 Nopember 2018.

http://imamsuprayogo.com/ diakses 25 November 2018. 